FINAL REPORT

September 15, 1998 to March 14, 2005

U.S. Department of Energy

\title{
PHYSICAL, CHEMICAL AND STRUCTURAL EVOLUTIION OF ZEOLITE-CONTAINING WASTE FORMS PRODUCED FROM METAKAOLINITE AND CALCINED SODUIM BEARING WASTE (HLW AND/OR LLW)
}

Michael W. Grutzeck

\author{
Materials Research Institute \\ Materials Research Laboratory \\ The Pennsylvania State University \\ University Park, PA 16802
}

EMSP Project Number 81963

Grant Number DE-FG07-98ER45726

Roland F. Hirsch (DOE Germantown MD)

Chet Miller (DOE Washington DC)

Ker-Chi Chang (DOE Washington DC)

Elizabeth Dahl (DOE Idaho Falls ID)

Prepared June 22, 2005 


\section{Research Objective}

Zeolites are extremely versatile. They can adsorb liquids and gasses and serve as cation exchange media. They occur in nature as well cemented deposits. The ancient Romans used blocks of zeolitized tuff as a building material. Using zeolites for the management of radioactive waste is not a new idea, but a process by which the zeolites can be made to act as a cementing agent is. Zeolitic materials are relatively easy to synthesize from a wide range of both natural and man-made substances. The process under study is derived from a well known method in which metakaolin (an impure thermally dehydroxylated kaolinite heated to $\sim 700^{\circ} \mathrm{C}$ containing traces of quartz and mica) is mixed with sodium hydroxide $(\mathrm{NaOH})$ and reacted in slurry form (for a day or two) at mildly elevated temperatures. The zeolites form as finely divided powders containing micrometer $(\mu \mathrm{m})$ sized crystals. ${ }^{1}$ However, if the process is changed slightly and only just enough concentrated sodium hydroxide solution is added to the metakaolinite to make a thick crumbly paste and then the paste is compacted and cured under mild hydrothermal conditions $\left(60^{\circ}-200^{\circ} \mathrm{C}\right)$, the mixture will form a hard ceramic-like material containing distinct crystalline tectosilicate minerals (zeolites and feldspathoids) imbedded in an X-ray amorphous hydrated sodium aluminosilicate matrix. ${ }^{2,3,4,5}$ Due to its lack of porosity and vitreous appearance we have chosen to call this composite a "hydroceramic". See Figure 1.

Similar to zeolite powders, a hydroceramic is able to sequester cations in both lattice positions and within the channels and voids present in its tectosilicate framework structure. It can also accommodate a wide range of salt molecules (e.g., sodium nitrate and nitrite) within these same openings thus rendering them insoluble. Due to its gel-like character, the matrix also develops significant physical strength. The obvious similarities between a hydroceramic waste form and a waste form based on solidified Portland cement grout are only superficial, because their chemistries are entirely different. In addition to being vastly superior to conventional Portland cement grouts with respect to Na-salt retention, standard radwaste leach protocols (PCT and TCLP) have shown that hydroceramics also do a better job of immobilizing the RCRA-toxic and radioactive components of "sodium bearing wastes" (SBWs). ${ }^{5}$

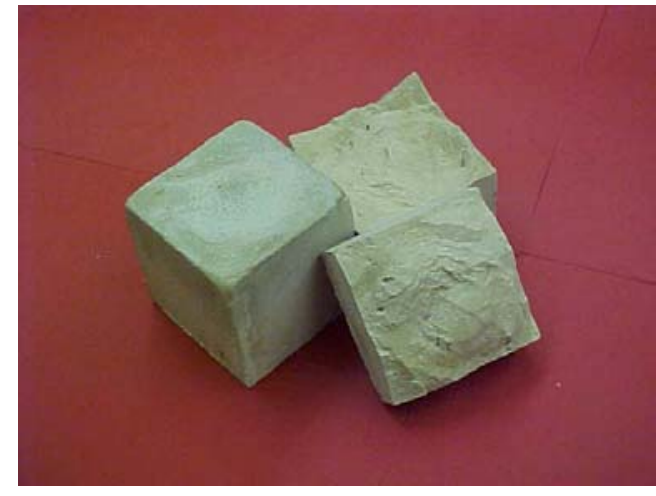

Figure 1. $150 \mathrm{~g}$ metakaolinite mixed with $130 \mathrm{~g} 15 \mathrm{M} \mathrm{NaOH}$ and cured at $90^{\circ} \mathrm{C}$ overnight.

The definition of a hydroceramic is: A monolithic solid produced by a hydration reaction. Generally a powder of some sort is mixed with a solution (normally sodium hydroxide) to form a

\footnotetext{
${ }^{1}$ Breck, D.W., Zeolite Molecular Sieves, 380 pp., Wiley-Interscience (1974).

${ }^{2}$ Grutzeck, M.W. and Siemer, D.D., "Zeolites Synthesized from Class F Fly Ash and Sodium Aluminate Slurry," J. Amer. Ceram. Soc. 80, 2449-53 (1997).

${ }^{3}$ Palomo, A., M.T. Blanco-Varela, M.L. Granizo, F. Puertas, T. Vazquez and M.W. Grutzeck, "Chemical Stability of Cementitious Materials Based on Metakaolin," WM'98 Proceedings March 1-5, 1998, Tucson, AZ, WM Symposia, Inc., Tucson (1998).

${ }^{4}$ Palomo, A., M.W. Grutzeck and M.T. Blanco, "Alkali Activated Fly-Ashes: A Cement for the Future," Cem. Concr. Res. 29, 1323-1330 (1999).

${ }^{5}$ Siemer, D.D., M.W. Grutzeck, D.M. Roy, B.E. Scheetz, "Zeolite Waste Forms Synthesized from Sodium Bearing Waste and Metakaolinite," WM'98 Proceedings March 1-5, 1998, Tucson, AZ.
} 
solid that has ceramic like properties. Although the process and outcome is similar to what happens when we mix Portland cement and water, the chemistry is very different. For example, metakaolinite can be mixed with concentrated $\mathrm{NaOH}$ and cured at $90^{\circ} \mathrm{C}$ for 24 hours to produce a solid having little or no porosity and a compressive strength in the range of 4,000 psi. ${ }^{6,7,8,9}{ }^{10} \mathrm{In}$ a sense, the name "hydroceramic" is an umbrella term for monolithic hydrated solids that can be produced in a single step (as above) or in two steps in which additional metakaolinite and 4M $\mathrm{NaOH}$ are mixed with a treated SBW calcine powder for example, in which case the metakaolinite and $\mathrm{NaOH}$ function as a binder for the dry calcine powder. All solids and the phases that form have their home in the system: $\mathrm{Na}_{2} \mathrm{O}-\mathrm{Al}_{2} \mathrm{O}_{3}-\mathrm{SiO}_{2}-\mathrm{H}_{2} \mathrm{O}$ rather than those based in the system $\mathrm{CaO}-\mathrm{Al}_{2} \mathrm{O}_{3}-\mathrm{SiO}_{2}-\mathrm{H}_{2} \mathrm{O}$ which are the purview of traditional Portland and refractory cement scientists. Hydroceramics can have a wide range of components, but in this instance we are concentrating on those hydroceramics that are made with metakaolin and $\mathrm{NaOH}$ solutions.

Metakaolin, either alone or preblended with small amounts of vermiculite (improves Cs retention) and/or sodium sulfide (which acts as a redox buffer and RCRA metal precipitant) is mixed with properly pretreated (thermally or chemically) SBW plus sufficient $4 \mathrm{M} \mathrm{NaOH}$ solution and shear mixed to produce a modeling clay-like "paste". Mixing is accomplished using shear mixers commonly used by the ceramic industry after which the paste can be extruded and compacted in a metal container and then "soaked" (precured) for a few hours at $40^{\circ} \mathrm{C}$ prior to implementation of the curing process. If a curing temperature $<100^{\circ} \mathrm{C}$ is chosen, a well-insulated building equipped with space heaters can serve as both the interim storage facility and "curing shed". If a faster cure is desired, curing must be done at higher temperatures in an autoclave ("pressure cooker") or canisters designed to act as pressure vessels ${ }^{11}$. In both instances the end product is a monolithic solid (a.k.a. hydroceramic waste form) that is both robust and insoluble enough to qualify as an alternate waste form for solidifying all SBW. Unfortunately, not all SBW is the same, some can be solidified by direct mixing with metakaonite while others require a thermal or chemical pretreatment step to reduce nitrate and nitrite content prior to solidification. A waste treatment system consisting of a relatively simple calciner/reformer close coupled with a hydroceramic grout mixer could prove to be an efficient solution to many of DOE's reprocessing waste treatment problems. The objective of this study was to work out the details of how the process could be applied to both the caustic-type SBWs stored at the Hanford and Savannah River sites and the already calcined acidic SBW in storage at the Idaho National Engineering \& Environmental Laboratory (INEEL). The goal was to develop a clearer understanding of the advantages and limitations of hydroceramic waste forms, i.e. the effect of processing variables, reaction kinetics, crystal and phase chemistry, and microstructure on their performance.

\footnotetext{
${ }^{6}$ Palomo, A. and F.P. Glasser, “Chemically-Bonded Cementitious Material Based on Metakaolin,” Br. Ceram. Trans. J91, 107-112 (1992).

${ }^{7}$ Palomo, A., M.T. Blanco-Varela, M.L Granizo, F. Puertas, T. Vazquez and M.W. Grutzeck, "Chemical Stability of Cementitious Materials Based on Metakaolin," Cem. Concrete Res. 29, 997-1004 (1999).

${ }^{8}$ Palomo, A., M.W. Grutzeck and M.T. Blanco, “Alkali-Activated Fly Ashes a Cement for the Future," Cem. Concr. Res. 29, 1323-1329 (1999).

${ }^{9}$ Granizo, M.L., M.T. Blanco-Varela, “Alkaline Activation of Metakaolin: Influence of Synthesis Parameters," in Proc. 10 ${ }^{\text {th }}$ ICCC, Vol 3, Gothenberg, Sweden (1997).

${ }^{10}$ Granizo, M.L., M.T. Blanco-Varela, "Alkaline Activation of Metakaolin: Isothermal Conduction Calorimetery Study,” J. Therm. Analy. 52, 957-965 (1998).

${ }^{11}$ Such vessels would not have to be especially massive or expensive; for example, domestic water heaters are designed for pressures up to $150 \mathrm{psig}$ - which corresponds to a curing temperature of $185^{\circ} \mathrm{C}$.
} 
Types of Low Activity Sodium Bearing Waste

Over the past six years, we have optimized the process of making hydroceramic waste forms. We have found that the key to success ultimately hinges on the nitrate/nitrite content of the SBW. Because SBW is nominally a $\mathrm{NaOH}$ solution containing varying amounts of $\mathrm{NaNO}_{3}$ and $\mathrm{NaNO}_{2}$ and lesser amounts of other salts, the SBW can, within limits act as a reactant and be used as a starting material to make a hydroceramic waste form. The chemistry of the reaction is similar to that used by industry to synthesize zeolites, however the processing is very different. Zeolite synthesis is usually carried out in open vessel filled with boiling but dilute caustic solution containing soluble sources of alumina and silica. In order to make a hydroceramic however one mixes only enough concentrated $\mathrm{NaOH}$ with the metakaolinite (aluminosilicate) to make a thick but coherent paste. The paste is molded and cured until hard, usually in a matter of hours at $90^{\circ}-200^{\circ} \mathrm{C}$. The process is hydration driven and zeolite $\mathrm{A}$ and hydroxysodalite form more slowly at $90^{\circ} \mathrm{C}$ than at $190^{\circ} \mathrm{C}$, but it has been shown that the end results (phase formation and leachability) are much the same. After a month at $90^{\circ} \mathrm{C}$ leachabilities begin to approach each other $^{12}$. What follows is a brief summary of the general guidelines that dictate how one can go about making hydroceramic waste forms from SBW. For ease of discussion we have divided low activity SBW stored at Hanford, Savannah River and INEEL into two types based upon their nitrate/nitrite content.

\section{Low $\mathrm{NO}_{x} \mathrm{SBW}$}

It has been found that SBW containing nitrate salts will react with metakaolin and form a combination of phases including zeolite A and cancrinite. It is suggested that phases based upon the cancrinite structure can host one mole of $\mathrm{NO}_{\mathrm{x}}$ per four moles of $\mathrm{Na}$ in their structure as the following hypothetical formula suggests: $\left[\mathrm{Na}_{8} \mathrm{Al}_{6} \mathrm{Si}_{6} \mathrm{O}_{24}\left(\mathrm{NO}_{3}\right)_{2} \bullet 1-5 \mathrm{H}_{2} \mathrm{O}\right]$. The $\mathrm{NO}_{\mathrm{x}} / \mathrm{Na}$ molar ratio is 0.25 or 25 mole $\%$. Thus hydroceramics can be made from low $\mathrm{NO}_{\mathrm{x}} \mathrm{SBW}$ without any pretreatment by mixing it directly with metakaolinite if the mole fraction of nitrate and nitrite ions divided by the total moles of $\mathrm{Na}$ ions in the SBW does not exceed $\sim 25 \%$ [i.e. $\mathrm{M}_{\mathrm{NO}^{-}}+$ $\mathrm{M}_{\mathrm{NO}^{-}} \div \mathrm{M}_{\mathrm{Na}^{+}} \mathrm{x} 100<25 \%$ ]. The liquid SBW is simply mixed with metakaolinite and cured, a process we are calling "direct solidification." Normally the hydration reaction will produce zeolites that host the sodium in channels and cavities in the structure, however, when nitrate and nitrite are present, other tectosilicate phases that are able to host anions in their structures (i.e. cancrinite) form along with the zeolites. Thus the combination of hydrated phases that form allow one to solidify low $\mathrm{NO}_{\mathrm{x}} \mathrm{SBW}$ (which by definition now becomes $\mathrm{NO}_{\mathrm{x}} / \mathrm{Na} \leq 0.25$ ) in a single step. The combination leads to low leachability for both sodium and nitrate/nitrite. Data are presented that suggest direct solidification of low $\mathrm{NO}_{x} \mathrm{SBW}$ can provide strength and leach behavior that compares favorably to EA glass.

\section{High $\mathrm{NO}_{\mathrm{x}} \mathrm{SBW}$}

High $\mathrm{NO}_{\mathrm{x}}$ SBW contains more than 25 mole $\%\left[\mathrm{M}_{\mathrm{NO} 3}+\mathrm{M}_{\mathrm{NO} 2} \div \mathrm{M}_{\mathrm{Na}} \mathrm{x} 100\right]$ nitrate and nitrite salts relative to its $\mathrm{NaOH}$ content. The boundary between the two types of SBW is a function of how much $\mathrm{NO}_{\mathrm{x}}$ can be accommodated by phases such as the proposed cancrinite-like phase. Since hydroceramics are zeolite/feldspathoid based and even pure cancrinite can not host all of the nitrate and nitrite in a high $\mathrm{NO}_{\mathrm{x}} \mathrm{SBW}$, soluble salts will remain behind as a second phase dispersed in the zeolite matrix. These are soluble and easily leached, making the waste

\footnotetext{
${ }^{12}$ Bao, Y. and S. Kwan, D.D. Siemer and M.W. Grutzeck, "Binders for Radioactive Waste Forms made from pretreated Calcined Sodium Bearing Waste," J. Materls. Sci. 39, p. 481-488 (2004).
} 
form unacceptable. Due to this fact, high $\mathrm{NO}_{\mathrm{x}} \mathrm{SBW}$ must first be pretreated in some fashion to reduce its nitrate/nitrite content to acceptable levels. INEEL used fluidized bed calcination to calcine their acid waste, but stopped short of calcining their SBW; nevertheless, calcination will work. Laboratory experiments described later show that an optimum calcination temperature for most SBW mixed with sucrose and metakaolin/kaolin is $525^{\circ} \mathrm{C}$ overnight. The calcine is nearly X-ray amorphous, granular and has very low leachability. Existing SBW at Hanford and Savannah River could be calcined in a rotary or vertical kiln, but generally these processes produce "dusty" products and "dusty" off gasses. The DOE is currently evaluating a Studsvik steam reformer using basically the same starting materials injected into a fluidized bed containing alumina, charcoal, and iron oxide heated by superheated steam at $\sim 725^{\circ} \mathrm{C} .{ }^{13,14}$

In both processes (calcination and pyrolysis), nitrate and nitrite as well as organics are destroyed and the product that forms consists of tectosilicates (amorphous at $\sim 525^{\circ} \mathrm{C}$ and nepheline and nosean at $\sim 725^{\circ} \mathrm{C}$ ). The resulting processed SBWs have varying degrees of granularity ranging from powders to flakes to granules. It is demonstrated later that a simulated waste based upon an average Hanford Tank low activity SBW could be calcined as a function of temperature and then solidified using a hydroceramic binder consisting of additional metakaolinite and $4 \mathrm{M} \mathrm{NaOH}$ solution. It is further demonstrated that the hydroceramic performed much better than a similarly solidified Portland cement based monolith. Hydroceramic monoliths containing calcine or steam reformed material can be solidified forming monoliths that have strength, low leachability and phase composition that is compatible with Yucca Mountain strata should the need arise to ship these materials off site ${ }^{12}$.

Current processing choices for SBW are summarized in Table 1. It is uncertain at this time what would happen to large amounts of organics should they be present in the SBW streams. Small amounts may be accommodated by the zeolites, but very large amounts of legacy organic waste such as that in Tank $48 \mathrm{H}$ at Savannah River containing 250,000 gallons of alkaline slurry with tetraphenylborate solids may not work without some pretreatment. Calcination/steam reforming will oxidize the organic fractions, so at this point in time, thermal pretreatment is the only process that has been completely verified. Chemical pretreatment and direct solidification will not oxide the organics and thus the fate of the organic fraction in a hydroceramic made with them is still unknown. The current study has focused on direct solidification of simulated wastes that are relatively free of organics.

Table 1. Potential processing schema for all types of low activity SBW.

\begin{tabular}{|l|l|l|l|l|}
\hline SBW Type & Additives & Curing Conditions & Binder & Final Product \\
\hline \hline Low $\mathrm{NO}_{\mathrm{x}}$ & metakaolin & $90-190^{\circ} \mathrm{C}$ & --------------- & hydroceramic \\
\hline High $\mathrm{NO}_{\mathrm{x}}$ & $\begin{array}{l}\text { kaolin, metakaolin } \\
+ \text { sucrose }\end{array}$ & $\begin{array}{l}525^{\circ} \mathrm{C} \mathrm{calcination} \\
\text { or steam reform }\end{array}$ & $\begin{array}{l}\text { metakaolin }+ \\
4 \mathrm{M} \mathrm{NaOH}\end{array}$ & hydroceramic \\
\hline High $\mathrm{NO}_{\mathrm{x}}$ & Al and Si metals & Ambient to $50^{\circ} \mathrm{C}$ & $\begin{array}{l}\text { metakaolin }+ \\
4 \mathrm{M} \mathrm{NaOH}\end{array}$ & hydroceramic \\
\hline
\end{tabular}

\footnotetext{
${ }^{13}$ Jantzen, C.M., Engineering Study of the Hanford Low Activity Waste (LAW) Steam Reforming Process, WSRCTR-2002-00317/SRT-RPP-2002-00163, 38pp., Westinghouse Savannah River Co., Aiken, SC (2002).

${ }^{14}$ Jantzen, C.M., Characterization and Performance of a Fluidized Bed Steam Reforming (FBSR) Product as a Final Waste Form, WSRC-MS-2003-00595, 13 pp. Westinghouse Savannah River Co., Aiken, SC (2002). Also in publication as part of the "Environmental Issues and Waste Management Technologies in the Ceramic and Nuclear Industries VIII” series (in press).
} 
Continuing work on simulated Hanford and Savannah River SBW (Low $\mathrm{NO}_{\mathrm{x}}$ that are amenable to direct solidification) will focus on more complex formulations that include organics. Performance versus composition will be tracked in order to determine their fate in directly solidified hydroceramics. Because the process is carried out at ambient, organics will continue to be present during the binding phase of the hydroceramic making process and thus more research is needed to determine whether or not these organics will leach and cause problems down the road.

Leach Performance of Hydroceramics versus DOE reference Glasses

In each of the scenarios in Table 1, the dry ingredients are mixed with just enough liquid to produce a thick but cohesive paste that can be extruded/poured/vibrated into a steel canister that can be sealed and then heat treated at $90^{\circ}-190^{\circ} \mathrm{C}$ for $1-28$ days. During the curing process, the metakaolinite combines with the $\mathrm{NaOH}$ in the solution to form zeolitic ceramic-like solids that have leach characteristics comparable to DOE's EA glass and Hanford's AN-107 steam reform product. ${ }^{14}$ See Figure 2 for a comparison of performances. Normalized 7 day PCT data for the hydroceramic was calculated using Table $18,525^{\circ} \mathrm{C}, 7$ day PCT solution analyses. The $\mathrm{HC}$ was made with $525^{\circ} \mathrm{C}$ AN- 107 calcine and a metakaolinite $/ 4 \mathrm{M} \mathrm{NaOH}$ binder cured at $90^{\circ} \mathrm{C}$ for 1 day. The corresponding normalized PCT data for EA glass and AN-107 steam reformed material are taken from Jantzen ${ }^{14}$.

Physical-Chemical Properties of Hydroceramic Waste Forms

In addition to low leachability, hydroceramics generally have high strength and inherent phase stability in realistic geologic scenarios. Strengths of a Hanford calcine solidified with metakaolinite and $4 \mathrm{M} \mathrm{NaOH}$ at $90^{\circ} \mathrm{C}$ overnight ranged from 3-4 $\mathrm{MPa}$ with associated densities in the $1.1 \mathrm{~kg} / \mathrm{m}^{3}$ range $^{12}$. Phase stability is assured in geological setting because the waste form contains zeolites and feldspathoids. This has been found to be true in our experiments as well as by comparing EA glass performance against that of a hydroceramic under the conditions imposed by DOE's vapor hydration test (GDL-VHT) ${ }^{15}$. Under these conditions, glass is severely corroded (just as one would expect) while the hydroceramic is not affected due to the fact that the hydroceramic waste form already consists of stable hydrated phases while glasses do not ${ }^{16}$. It is no accident

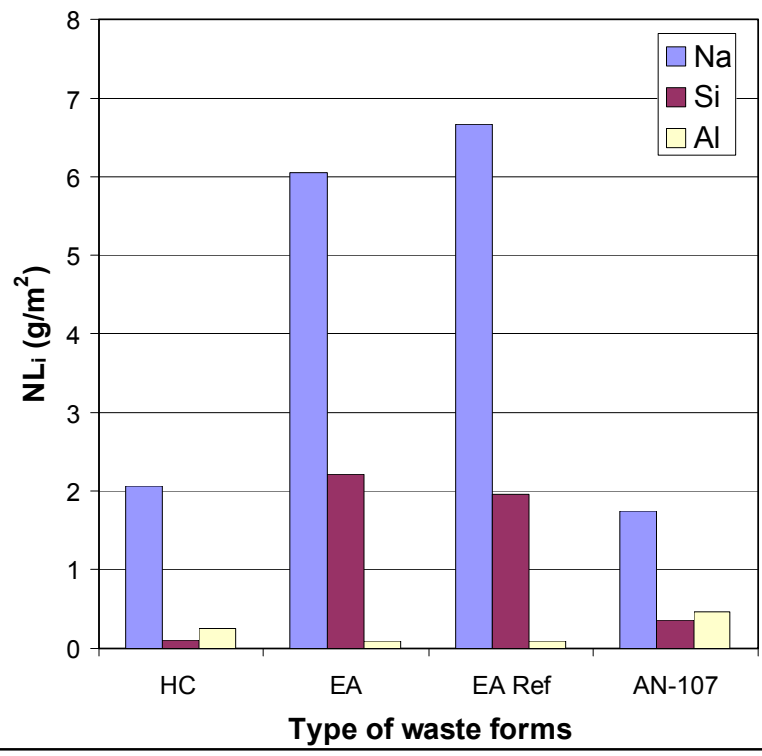

Figure 2. Waste form performance for hydroceramic made from AN-107 simulant (HC-Table $18: 525^{\circ} \mathrm{C} 7$ day PCT) compared to steam reformed $\mathrm{AN}-107$ calcine and $\mathrm{EA}$ Glass $^{13}$.

\footnotetext{
${ }^{15}$ Jirica, A., "Vapor Hydration Test Procedure, GDL-VHT," PNL Procedure No. CDL-VHT, Rev. 1, dated 2-26-00.

${ }^{16}$ Jiricka, J., J.D. Vienna, B.R. Allen, B.M. Jorgrnsen and D.E. Smith, "VHT Testing of Hanford LAW Glasses:

Preliminary Results," 535-541 in "Environmental Issues and Waste Management Technologies in the Ceramic and Nuclear Industries VI," edited by D.R. Spearing, G.L. Smith and R.L. Putnam, Ceram. Trans. Amer. Ceramic Society 119, Westerville, OH. (2001).
} 
that the tuff at Yucca Mountain is zeolitized or that zeolites are the major secondary mineral forming in the World's oceans. Zeolites are common alteration products of clays and volcanic and other related glasses. We emphasize that hydroceramic waste forms are already in nearequilibrium with the materials indigenous to today's proposed HLW repository, whereas the glass is, at best, metastable in that environment and has a high potential of becoming altered over the long term. Although the formation of zeolites from glass waste forms is not necessarily bad because the zeolites that form will continue to immobilize hazardous/toxic components, the fact that the process will not be controlled introduces a large and unnecessary degree of uncertainty. Changes in volume and in mechanical properties could cause containment problems.

We have also suggested that hydroceramic waste forms could represent a less costly and safer alternate to vitrification of the high sodium waste present in tanks at the Hanford and Savannah River sites. Because sodium bearing waste present in the form of supernate, salt cake and sludge wash water (collectively referred to as SBW) contains up to $70 \mathrm{wt} \%$ sodium nitrate/nitrite on a dry basis, vitrification would require a great deal of dilution (additions of glass making frit) to accommodate the sodium which in turn would necessitate a corresponding great increase in volume. Although not as critical in terms of volumes, aluminum content of some SBWs could also mandate further "composition adjustments" (dilution) to make glasses with suitable viscosities. A recent compilation of the cost of vitrification concluded that it now costs taxpayers $\$ 2,000,000$ to vitrify one cubic meter of glass that contains $\sim 30 \mathrm{wt} \%$ waste. DOE has estimated that each glass canister at Savannah River could cost upwards of $\$ 1,000,000$. If one does the math, the vitrification process for SBW at Hanford could raise the cost of DOE site cleanup by billions of dollars. ${ }^{17}$

It is relatively easy to visualize proposed cost savings if low $\mathrm{NO}_{\mathrm{x}} \mathrm{SBW}$ were turned into durable monoliths using simple metakaolinite additions and in-can curing at $90^{\circ} \mathrm{C}$. Cost savings if any are less obvious when dealing with high $\mathrm{NO}_{\mathrm{x}}$ waste now in storage at Hanford. Calcination or steam reforming or chemical reduction with $\mathrm{Al}$ and $\mathrm{Si}$ must first be carried out before it becomes possible to solidify the waste, but this means that a large investment in building a new facility would have to be made. Thus the cost savings vis à vis vitrification might not be there. The amount of building necessary for ambient reduction with $\mathrm{Al}$ and $\mathrm{Si}$ metal powders is probably the lowest of the current options. It has been discovered that equal molar quantities of $\mathrm{Al}$ and Si metals will reduce nitrate and nitrite to ammonia gas over a two week period. The reaction is gentle and controlled without much heat evolution and the reaction product that forms (cancrinite) seemingly contains a large proportion of $\mathrm{Cs}$, but then our simulant contains a very large amount of Cs (Table 7). If it is possible to reduce high $\mathrm{NO}_{\mathrm{x}} \mathrm{SBW}$ in this fashion, SBW with high levels of $\mathrm{Cs}$ and $\mathrm{Sr}$ and the like could possibly be solidified directly without thermal pretreatment. Were this possible, then cost savings become more obvious. Until quite recently, it was planned to remove cesium and strontium from the SBW at Savannah River, which is currently classified as high level waste (HLW), in order to convert it to low level waste (LLW) and then solidify it with Saltstone. At Hanford cesium has already been removed from the majority of the SBW. It seems plausible that the SBW at Savannah River (Low $\mathrm{NO}_{\mathrm{x}} \pm \mathrm{Cs}$ and $\mathrm{Sr}$ ) and perhaps the high $\mathrm{NO}_{\mathrm{x}} \mathrm{SBW}$ at Hanford (pretreated with $\mathrm{Al}+\mathrm{Si}$ metal converting it into a low $\mathrm{NO}_{\mathrm{x}} \mathrm{SBW}$ ) could be solidified with metakaolin without further processing.

Savannah River was committed to removing Cs and Sr using chemical pretreatment and then solidification of their remaining SBW (still in its nitrate/nitrite form) using Saltstone. However, if Cs removal proves to be unattainable at reasonable cost and safety, they do have a

\footnotetext{
${ }^{17}$ Siemer, Duane, INEEL, Personal communication.
} 
"last resort" option of using Saltstone to solidify the Cs containing SBW if state and federal regulations can be revised to meet the need. ${ }^{18}$ Unfortunately Saltstone is inherently soluble, much more so than a hydroceramic. It would be far better to explore in tank reduction of high $\mathrm{NO}_{\mathrm{x}} \mathrm{SBW}$ with $\mathrm{Al}+\mathrm{Si}$ powder. Preliminary experiments suggest that the oxidized Al and Si combine preferentially with $\mathrm{Cs}$ in solution and form cancrinite that precipitate forming a layer at the bottom of the tank. There is a possibility that cancrinite and/or the other zeolites that might form will incorporate lower valence $\mathrm{Tc}$ and $\mathrm{Cr}$ that may also form during the reduction of the SBW making it easy to remove most of the "elements of concern" via filtration. The SBW could then be mixed with metakaolinite and disposed in vaults in lieu of Saltstone.

Looking at the economics from the most liberal point as possible, Hanford's sodium bearing waste could be vitrified as a less durable "container glass" containing up to $15 \mathrm{wt} \%$ $\mathrm{Na}_{2} \mathrm{O}$, but even this glass will require adding large quantities of glass frit to the waste stream. In all cases costs and volumes of waste will still increase. Currently Hanford is evaluating Bulk Vitrification in a disposable container as an alternate to glass plant vitrification for approximately $1 / 2$ of its SBW. Bulk Vitrification is a rather "crude" process in which native soil is mixed with the SBW and loaded into a refractory lined dumpster sized container fitted with electrodes at each end. The solid is arc melted and allowed to cool in the container and then the entire unit becomes the waste package that is sent for disposal. We feel that a hydroceramic binder would be a more "scientifically" sound choice for this type of waste. In fact, if the Hanford SBW is low enough in nitrate and nitrite it could be mixed with metakaolin and used as tank fill. Its properties would be far superior to Portland cement grouts and could also help meet increasingly restrictive permitting requirements for tank closure.

\section{Research Progress}

During the tenure of our EMSP grant, it has been possible to provide proof of concept that a monolithic hydroceramic waste form can be produced from nearly all types of SBW. Processing has been optimized for two types of SBW based upon their ratio of nitrate/nitrite to $\mathrm{NaOH}$. The text below highlights progress made in each of the two past 3 year funding periods.

\section{First Three Years}

Two waste simulants (SRS 1 and 2) based on Savannah River's Tank 44 waste (Jantzen, personal communication) and a third based upon a recipe by Brough et al. ${ }^{19}$ for the average supernate composition of SBW in Hanford tanks were formulated using the recipes given in Table 2. It was realized rather early that their nitrate and nitrite content were detrimental to making hydroceramics by direct mixing processes (See Table 3: Raw SBW for composition), they hade very high nitrate/nitrite leach rates. Heating the SBW in air with a reducing agent such as sucrose led to the formation of $\mathrm{Na}_{2} \mathrm{CO}_{3}$ (Table 3-SBW + sucrose) which is soluble and thus adversely affected leachability as evidenced by the high $\mathrm{Na}$ content of the lechate. Thus it was decided to study thermal calcination in the presence of a reducing agent (sucrose) at a variety of temperatures with the addition of various sodium ion "getters" to see if carbonation could be

\footnotetext{
${ }^{18}$ Academy of Science Publication "Alternates for High Level Waste Salt Processing at the Savannah River Site" (http://www.nap.edu/books/0309071941/html).

${ }^{19}$ Brough, A.R., A. Katz, T. Bakharev, G-K. Sun, R.J. Kirkpatrick, L.J. Struble and J.F. Young, "Microstructural Aspects of Zeolite Formation in Alkali Activated Cements Containing High Levels of Fly Ash", in Microstructure of Cement-Based Systems/Bonding and Interfaces in Cementitious Materials, Mat. Res. Soc. Symp. Proc. Vol. $\underline{370}$, pp. 199-208, Materials Research Soc., Pittsburgh (1995).
} 
Table 2. Composition of Simulated SBWs used to make SBW Calcines (weights in grams/L)

\begin{tabular}{|c|c|c|c|}
\hline Component & SRS & SRS 2 & Hanford \\
\hline \hline $\mathrm{NaOH}$ & 456 & 456 & 82.682 \\
\hline $\mathrm{Al}\left(\mathrm{NO}_{3}\right)_{3} .9 \mathrm{H}_{2} \mathrm{O}$ & 32.32 & 32.32 & 133.5 \\
\hline $\mathrm{NaNO}_{2}$ & 95.2 & 95.2 & 36.911 \\
\hline $\mathrm{NaNO}_{3}$ & 95.2 & 95.2 & 36.205 \\
\hline $\mathrm{Na}_{2} \mathrm{CO}_{3}$ & 21.2 & 21.2 & 8.582 \\
\hline $\mathrm{CsNO}_{3}$ & - & 4.66 & - \\
\hline $\mathrm{Na}_{2} \mathrm{HPO}_{4}$ & - & - & 27.787 \\
\hline $\mathrm{KCl}$ & - & - & 2.833 \\
\hline $\mathrm{NaCl}$ & - & - & 0.110 \\
\hline $\mathrm{Na}_{2} \mathrm{~B}_{4} \mathrm{O}_{7} \cdot 10 \mathrm{H}_{2} \mathrm{O}$ & - & - & 3.894 \\
\hline $\mathrm{Na}_{2} \mathrm{SO}_{4}$ & - & - & 0.312 \\
\hline $\mathrm{Ni}\left(\mathrm{NO}_{3}\right)_{2} \cdot 6 \mathrm{H}_{2} \mathrm{O}$ & - & - & 0.442 \\
\hline $\mathrm{Ca}\left(\mathrm{NO}_{3}\right)_{2} .4 \mathrm{H}_{2} \mathrm{O}$ & - & - & 0.034 \\
\hline $\mathrm{Mg}\left(\mathrm{NO}_{3}\right)_{2} \cdot 6 \mathrm{H}_{2} \mathrm{O}$ & & & \\
\hline
\end{tabular}

reduced if not eliminated. It was hypothesized that, were a suitable host available to react with, the nascent $\mathrm{Na}$ ions, the $\mathrm{Na}$ would react with it rather than the $\mathrm{CO}_{2}$ in the furnace atmosphere. Colloidal aluminum hydroxide, Min-U-Sil, and metakaolinite were added to the SBW + sucrose mixture and fired at a variety of temperatures in order to produce something other than a soluble product. All calcines contained $20 \mathrm{~g}$ liquid SBW, $2.5 \mathrm{~g}$ sucrose and $11.9 \mathrm{~g}$ metakaolinite. The combination containing sucrose and metakaolinite fired in air at $525^{\circ} \mathrm{C}$ for 24 hours was found to contain the lowest amount of $\mathrm{CO}_{3}$, and to have acceptably low $\mathrm{NO}_{3}$ and $\mathrm{NO}_{2}$ concentrations (Table 3-next three columns labeled boehmite, quartz and metakaolinite). Also see Siemer et al. (2000) for a more detailed account of the effect of many more additives on carbonation and leachability. Also given in Table 3 (last column) are data for our initial cold calcination experiment. Adding Al metal alone added too much Al to make zeolites. Adding both Al and Si has solved the problem.

Table 3. Chemical analysis of treated SBW calcines based upon SRS Tank 44 Simulant 1.

\begin{tabular}{|l|l|l|l|l|l|l|}
\hline Wt.\% present & Raw SBW & $\begin{array}{l}\text { SBW }+ \\
\text { sucrose }\end{array}$ & $\begin{array}{l}\text { SBW + } \\
\text { sucrose }+ \\
\text { boehmite }\end{array}$ & $\begin{array}{l}\text { SBW }+ \\
\text { sucrose }+ \\
5 \mu \mathrm{m} \text { quartz }\end{array}$ & $\begin{array}{l}\text { SBW }+ \\
\text { sucrose }+ \\
\text { metakaolinite }\end{array}$ & $\begin{array}{c}\text { SBW }+ \text { Al } \\
\text { powder }\end{array}$ \\
\hline \hline $\mathrm{NO}_{3}$ (IC) & 4.5 & $<0.1$ & $<0.1$ & $<0.1$ & $<0.1$ & 1.5 \\
\hline $\mathrm{NO}_{2}$ (IC) & 4.8 & 0.45 & 0.13 & $<0.05$ & 0.08 & 2.3 \\
\hline $\mathrm{CO}_{3}$ & 0.83 & 43 & 9 & 15.3 & 8.0 & $\sim 0.4$ \\
\hline $\mathrm{Na}$ (ICPAES) & 25.4 & 41 & 27.4 & 22.5 & 20.0 & 35.6 \\
\hline $\mathrm{Al}$ (ICPAES) & 0.8 & 1.7 & 30.2 & 0.64 & 12.1 & 14.4 \\
\hline
\end{tabular}

PCT procedures were modified to facilitate rapid testing and evaluation as follows: The sample was ground to a powder in an agate mortar and sieved using piggy-backed 100 mesh and 200 mesh screens (75-149 micron size). One gram of the unwashed but sized sample was placed in a Teflon lined Parr bomb with $10 \mathrm{cc}$ deionized water at $90^{\circ} \mathrm{C}$ for 1 day. The solution was filtered and its electrical conductivity was determined using a conductivity probe and a Quickcheck Model 118 Conductivity-2 meter (Orion). Conductivity rather than a chemical 
analysis was used to screen the samples. It has been demonstrated that the sodium ion dominates the leachate in these tests. It is so abundant in the SBW and in the zeolites and feldspathoids in the hydroceramic that $\mathrm{Na}$ simply overwhelms other ions in the solution. Sodium ion concentration had been calculated, until as of late, by using standard conductivity data for $\mathrm{NaOH}$ solutions. During the second funding period a more formal approach was taken in which analytical data and conductivity were compared. A plot of the data currently used to screen samples is given in Figure 3. This plot was used to obtain $\% \mathrm{Na}$ leached during sample screening experiments. For sake of example, a 7 day PCT of EA glass tested out at $6.35 \mathrm{mS} / \mathrm{cm}$ which is equivalent to $\sim 11.9 \%$ total Na leached ${ }^{20}$. Seven day PCT test results for calcines made with additives are given in Table 4 . Note that the thermal calcination process $\left(525^{\circ} \mathrm{C}\right.$ for a few hours) has essentially converted all of the nitrate/nitrite in the SBW solution into oxides and carbonates as the sucrose is burnt off. Carbonate is higher than one might want due to the carbonation of the newly formed sodium oxide molecules. This can not be helped, but one does get less carbonate when other substances are added to the raw waste/sucrose mixture during the calcination process. The calcine made with sucrose and metakaolinite had the lowest (\% of the total amount available) leachability for $\mathrm{Na}$ and $\mathrm{Cs}$ as well as very low nitrate/nitrite.

Table 4. Typical 7-day PCT test results for Calcines made with different Na-Getters.

\begin{tabular}{|c|c|c|c|c|c|}
\hline Simulant & Raw Waste & Boehmite & Minusil & Metakaolinite & Cold Calcination \\
\hline \begin{tabular}{|l|} 
Ealk:Al:Si \\
atom ratios
\end{tabular} & $1: 1.03: 1.58$ & $1: 2.12: 1.58$ & $1: 1.02: 2.38$ & $1: 1.32: 2.06$ & $1: 1.35: 1.58$ \\
\hline$\% \mathrm{H}_{2} \mathrm{O}$ added & 29.3 & 25.6 & 27 & 28.5 & 28.5 \\
\hline $\mathrm{mS} / \mathrm{cm} @ 1 / 100$ & 0.379 & 0.246 & 0.236 & 0.145 & 0.279 \\
\hline $\mathrm{pH}$ & 10.7 & 10.5 & 10.5 & 10.3 & 11.1 \\
\hline Nitrite ppm & $555(26 \%)$ & 4 & $<1$ & $<1$ & $4(0.9 \%)$ \\
\hline Nitrate ppm & $302(14 \%)$ & 5 & $<1$ & 4 & $21(3.2 \%)$ \\
\hline Na ppm & $856(7.1 \%)$ & $514(5.5 \%)$ & $428(4.4 \%)$ & $346(3.6 \%)$ & $526(4.5 \%)$ \\
\hline Al ppm & 34 & 98 & 35 & 62 & 104 \\
\hline Si ppm & 43 & 46 & 45 & 42 & 86 \\
\hline $\mathrm{CO}_{3} \mathrm{ppm}$ & 202 & 38 & $\overline{553}$ & 350 & 462 \\
\hline Cs ppm & $0.083\left(0.086^{\circ}\right)$ & $\begin{array}{l}0.17 \\
(0.22 \%)\end{array}$ & $\begin{array}{l}0.053 \\
(0.068 \%)\end{array}$ & $\begin{array}{l}0.039 \\
(0.051 \%)\end{array}$ & \begin{tabular}{|l|}
0.19 \\
$(0.21 \%)$ \\
\end{tabular} \\
\hline
\end{tabular}

\footnotetext{
${ }^{20}$ EA Glass contains $16.9 \% \mathrm{Na}_{2} \mathrm{O}$. A conductivity of 6.35 is approximately equivalent to $1.5 \mathrm{~g} / \mathrm{l} \mathrm{Na}$. Doing the math and converting $\mathrm{g} \mathrm{Na}$ to moles $\mathrm{Na}$ and then to moles $\mathrm{Na}_{2} \mathrm{O}$ and then to grams in $10 \mathrm{cc}$ and then dividing that number by $0.169 \mathrm{~g} \mathrm{Na}_{2} \mathrm{O} / \mathrm{g}$ EA Glass one gets $\sim 11.9 \%$ leached.
}

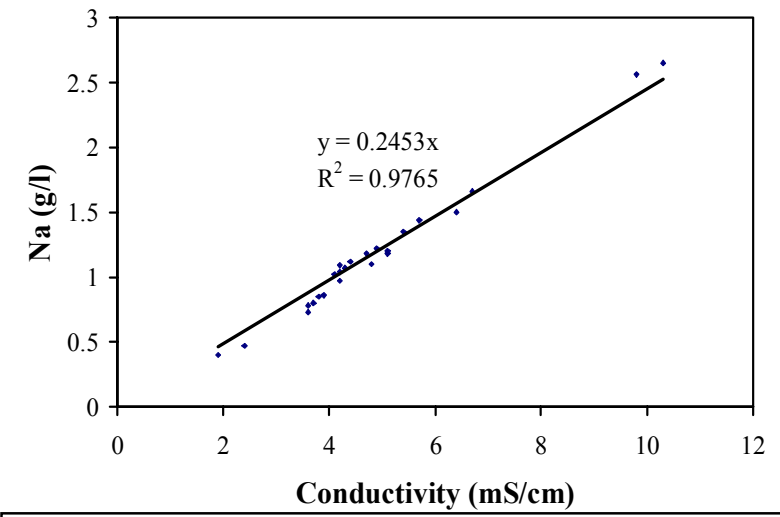

Figure 3. Conductivity versus $\mathrm{Na}^{+}$ concentration in leachate. It is notable that the slope of this curve is approximately the same as $\mathrm{NaOH}$ dissolved in $\mathrm{H}_{2} \mathrm{O}$. 
Because the calcines were powders, they were each made into monoliths using a binder consisting of metakaolinite and various solutions mixed to paste-like consistency and then curing them as a function of temperature. It seemed reasonable to proceed in this fashion because zeolites were being formed in the calcines and it was thought that more zeolites would form during the solidification process if metakaolinite and alkali were used as the binder as well. Conductivity measurements described earlier were used to evaluate the PCT leaching performance of the monoliths (Figure 4). It is notable that leach performance improves with time through 14 days and then levels out. Due to the fact that the Tank 44 waste simulate has a great excess of free $\mathrm{NaOH}$ relative to nitrate/nitrite ( $>4: 1$ mole wise) it is actually a low $\mathrm{NO}_{\mathrm{x}} \mathrm{SBW}$ that one is able solidify directly by mixing it with additional metakaolin. This duality is discussed later the Second Three Years section below.

It was also discovered that very pure metakaolinite (rather than impure metakaolin) such as that sold by Engelhard provided better leach resistance (higher reactivity) when it was used to make a monolith from the calcines, but at the expense of strength, they had very little to none at all. However, by adding $5 \mu \mathrm{m}$ quartz (Min-U-Sil) strength was regained without compromising leach resistance.

Lastly, efforts were made to denitrate the waste without the use of heat. One SBW sample was "cold de-nitrated" at room temperature by adding aluminum powder to the caustic rich solution containing nitrate/nitrite salts. The aluminum served as a reducing agent and caused the evolution of ammonia. See Tables 3 and 4 (right-hand most columns). These results have spurred the current thrust on further exploring $\mathrm{Al}$ and $\mathrm{Si}$ reduction proposed for the coming three years.

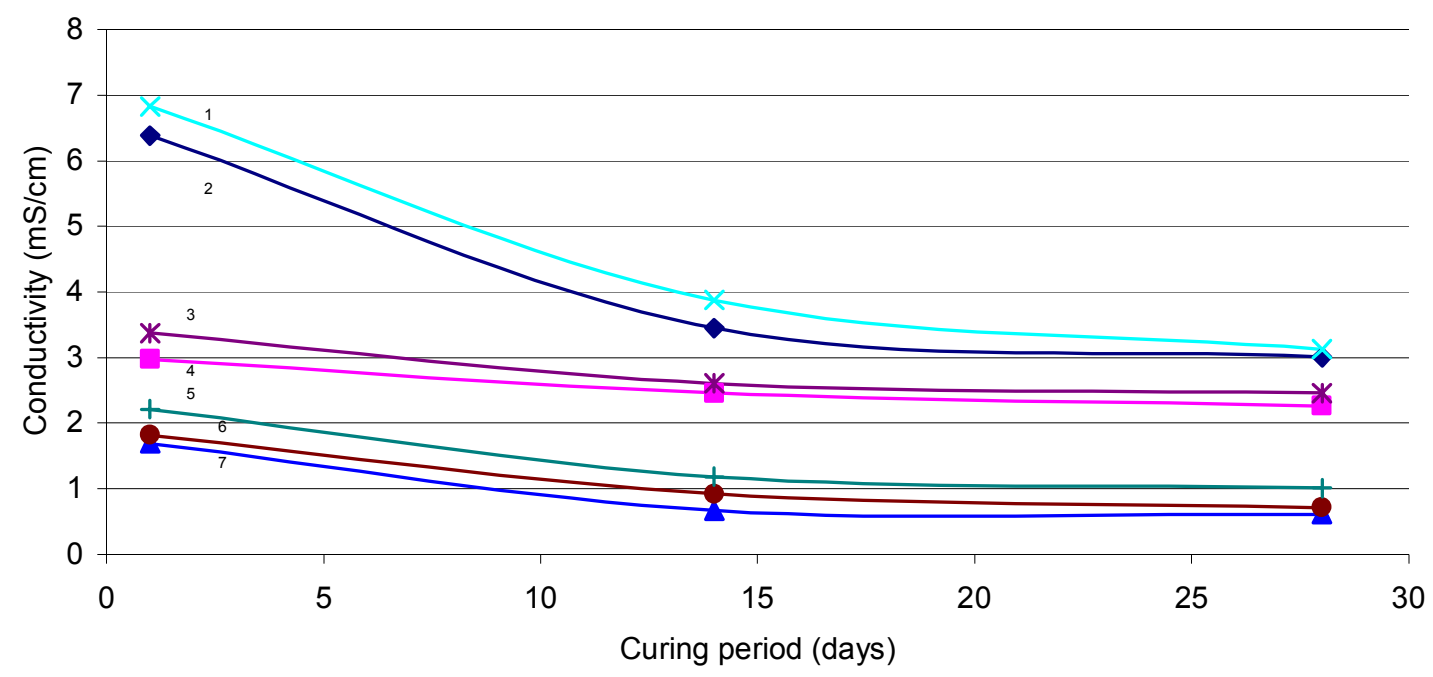

Figure 4 Modified 1-day PCT data for hydroceramics made with $60 \mathrm{wt} \%$ SRS and Hanford Calcines, $40 \mathrm{wt} \%$ metakaolinite and solution that were cured at $115^{\circ} \mathrm{C}$ (Curves $1-4,6,7$ ) or $90^{\circ} \mathrm{C}$ (Curve 5) as a function of time. Curve 1: SRS Calcine 1 and $2 \mathrm{M} \mathrm{NaOH}$; Curve 2: SRS Calcine 1 and water; Curve 3: SRS Calcine 2 and 2M NaOH; Curve 4: SRS Calcine 2 and water; Curve 5: Hanford Calcine and water; Curve 6: Hanford Calcine and 2MNaOH; Curve 7: Hanford Calcine and water. 


\section{Conclusions}

Calcines as well as hydroceramics made with impure metakaolin from Troy Idaho tended to outperform all other aluminosilicate additives. Hydroceramics have a ceramic structure and contain zeolitic phases such as zeolite A and hydroxysodalite. This makes them accommodate sodium within their matrix with relatively little additional processing. They have low leachability and compare favorably with DOE's EA glass waste form. Cesium containing calcines were better accommodated by hydroceramics made with additional sodium hydroxide and vermiculite. The overall low cost and low temperature processing enhance the potential utility of hydroceramics in providing an alternate means for the disposal of sodium bearing wastes. By way of summary, Table 4 and Figure 2 almost speak for themselves. The data given there represent the results of PCT tests run on typical calcines and hydroceramic monoliths made from the calcines using a metakaolinite binder. The numbers in parentheses in Table 4 represent the \% of the total amount present in the sample that was leached. These are good numbers, comparable to glass waste forms even before being formed into monoliths.

Publications During First Three Years

Grutzeck, M.W., D.D. Siemer, "Zeolites Synthesized from Class F Fly Ash and Sodium Aluminate Slurry", J. Amer. Ceram. Soc. 80, 2449-2453 (1997).

Siemer, D.D., M.W. Grutzeck, D.M. Roy, B.E. Scheetz, "Zeolite Waste Forms Synthesized from Sodium Bearing Waste and Metakaolinite", WM98, Tucson AZ, March 1-5, 1998. CD of Proceedings Published September (1998) also published on the World Wide Web.

Siemer, D.D., M.W. Grutzeck, B.E. Scheetz, "Comparison of Materials for Making Hydroceramic Waste Forms," 161-167 in "Environmental Issues and Waste Management Technologies in the Ceramic and Nuclear Industries V," edited by G.T. Chandler and X. Feng, Ceram. Trans. Amer. Ceramic Society 107, Westerville, OH. (2000).

Krishnamurthy, N., M.W. Grutzeck, S. Kwan and D.D. Siemer, "Hydroceramics for Savannah River Laboratory's Sodium Bearing Waste," 337-344 in "Environmental Issues and Waste Management Technologies in the Ceramic and Nuclear Industries VI," edited by D.R. Spearing, G.L. Smith and R.L. Putnam, Ceram. Trans. Amer. Ceramic Society 119, Westerville, OH. (2001).

Siemer, D.D., J. Olanrewaju, B.E. Scheetz, N. Krishnamurthy and M.W. Grutzeck, "Development of Hydroceramic Waste Forms," 383-390 in "Environmental Issues and Waste Management Technologies in the Ceramic and Nuclear Industries VI," edited by D.R. Spearing, G.L. Smith and R.L. Putnam, Ceram. Trans. Amer. Ceramic Society 119, Westerville, OH. (2001).

Siemer, D.D., J. Olanrewaju, B.E. Scheetz, and M.W. Grutzeck, "Development of Hydroceramic Waste Forms for INEEL Calcined Waste," 391-398 in "Environmental Issues and Waste Management Technologies in the Ceramic and Nuclear Industries VI," edited by D.R. Spearing, G.L. Smith and R.L. Putnam, Ceram. Trans. Amer. Ceramic Society 119, Westerville, OH. (2001).

\section{$\underline{\text { Second Three Years }}$}

The second three year funding period focused on scale-up issues, the development of a classification scheme for low activity SBW, a demonstration of solidification of a low $\mathrm{NO}_{\mathrm{x}} \mathrm{SBW}$ (Savannah River Tank 44) in two ways: directly, and after first calcining it and then solidifying it with a hydroceramic binder, simulating Hanford's Tank AN-107 waste in response to the publication of a SRL document on steam reformed Hanford's high $\mathrm{NO}_{\mathrm{x}}$ waste treated in a 
Studsvik reactor run at $725^{\circ} \mathrm{C}^{13}$, using the $\mathrm{AN}-107$ calcine to study high $\mathrm{NO}_{\mathrm{x}}$ waste solidification using a hydroceramic binder and the performance of metakaolin/4M NaOH versus Portland cement/water as a binder phase for preexisting calcines/steam reformed materials.

Scale-Up Testing

Scaling up a reaction provides a challenge not recognized in smaller samples. One issue is certainly the heat of hydration and settling. Although a scale up from gram sized samples to a four inch cube made with simulated AN-107 SBW calcine is not a very large scale up, if one considers that previous work, it is a rather significant step in the right direction. Our intent was to see if scale up would introduce variables in strength, leachability, phase formation and the like depending upon the sampling position in the cube. Testing described below indicated that no such problems were found. The four inch hydroceramic cube was evaluated by taking subsamples from various surfaces, edges and interior and leach testing them as a function of phase composition. The effects of excess heat of reaction were not noticeable.

The simulant used was based upon a recipe published by Jantzen ${ }^{13}$ for the SBW in Hanford Tank AN-107. The ingredients used to make the simulant are given later in Table 14. Because this is a high $\mathrm{NO}_{\mathrm{x}} \mathrm{SBW}$ it had to be calcined prior to solidification. This was carried out in the usual fashion by adding sugar and metakaolinite to the SBW and calcining it at $525^{\circ} \mathrm{C}$. More details are given in the Optimization Section later. To make the cube, $480 \mathrm{~g}$ of the AN-107 calcine was blended with $320 \mathrm{~g}$ metakaolin and $720 \mathrm{~mL} 4 \mathrm{M} \mathrm{NaOH}$. This formulation is pourable, so it made it easy to transfer the mix to a four-inch cube mold. The sample was precured at $40^{\circ} \mathrm{C}$ and $50 \%$ humidity overnight, then it was demolded and further cured in a sealed can at $90^{\circ} \mathrm{C}$ for 24 hours. After removing the sample from the can it was dried at $50^{\circ} \mathrm{C}$ overnight and its volumetric density was determined $(1.03 \mathrm{~g} / \mathrm{cc})$. Then it was cut into 27 pieces. After sanding, each small cube sample was nominally a 1 x 1 x 1 inch in size. The subsamples consisted of 1 middle piece, 8 corner pieces, 6 side middle pieces and 12 side pieces. The cubes were defined as combinations 123, abc and TML were tracked during leaching and testing. All samples were tested using a 1 day PCT, but several were also tested using a 7 day PCT. The compressive strength of the samples was also tested prior to grinding them for PCT. All data sets are given in Table 5.

Table 5. The Compressive Strength (MPa) and PCT Conductivity (mS/cm) of 1 inch Blocks.

\begin{tabular}{|c|c|c|c|c|c|c|c|c|c|c|c|}
\hline & $1 \mathrm{aT}$ & $2 \mathrm{aT}$ & $3 \mathrm{aT}$ & & $1 \mathrm{aM}$ & $2 \mathrm{aM}$ & $3 \mathrm{aM}$ & $1 \mathrm{aL}$ & $2 \mathrm{aL}$ & $3 \mathrm{aL}$ \\
\hline \hline Strength & 3.14 & 3.41 & 4.26 & & 3.72 & 3.25 & 3.33 & 2.66 & 3.28 & 3.03 \\
\hline PCT-1 d & 3.20 & 3.30 & 2.80 & 2.40 & 2.00 & 2.20 & 2.60 & 2.30 & 2.40 \\
\hline PCT-7 d & 3.40 & & & & & 2.20 & 2.60 & 2.60 & 2.50 & \\
\hline & & & & & & & & & & \\
\hline & $1 \mathrm{bT}$ & $2 \mathrm{bT}$ & $3 \mathrm{bT}$ & $1 \mathrm{bM}$ & $2 \mathrm{bM}$ & $3 \mathrm{bM}$ & $1 \mathrm{bL}$ & $2 \mathrm{bL}$ & $3 \mathrm{bL}$ \\
\hline Strength & 2.52 & 2.83 & 3.33 & 3.28 & 3.67 & 3.40 & 2.56 & 3.76 & 2.79 \\
\hline PCT-1 d & 3.60 & 2.70 & 3.50 & 2.00 & 2.50 & 2.20 & 2.80 & 1.90 & 2.20 \\
\hline PCT-7 d & 4.00 & & & 2.30 & 2.60 & & & & \\
\hline & & & & & & & & & \\
\hline & $1 \mathrm{cT}$ & $2 \mathrm{cT}$ & $3 \mathrm{cT}$ & $1 \mathrm{cM}$ & $2 \mathrm{cM}$ & $3 \mathrm{cM}$ & & $1 \mathrm{cL}$ & $2 \mathrm{cL}$ & $3 \mathrm{cL}$ \\
\hline Strength & 3.57 & 2.91 & 3.82 & & 2.73 & 3.37 & 3.27 & & 2.00 & 2.42 & 3.05 \\
\hline PCT-1 d & 3.70 & 3.80 & 2.50 & 2.40 & 1.90 & 2.40 & & 2.70 & 2.10 & 2.50 \\
\hline PCT-7 d & 3.90 & & & & 2.10 & & & & \\
\hline
\end{tabular}


The average compressive strength for the blocks was $3.16 \mathrm{MPa} \pm 0.5 \sigma$ and the average PCT for 1 day was $2.61(\mathrm{mS} / \mathrm{cm})$. The relationship between compressive strength and conductivity of the leachate is illustrated in Figure 5. The compressive strength and PCT conductivity of the individual blocks have little if any correlation, which indicates that the homogeneity of the four inch samples was quite good. There is just the slightest suggestion that

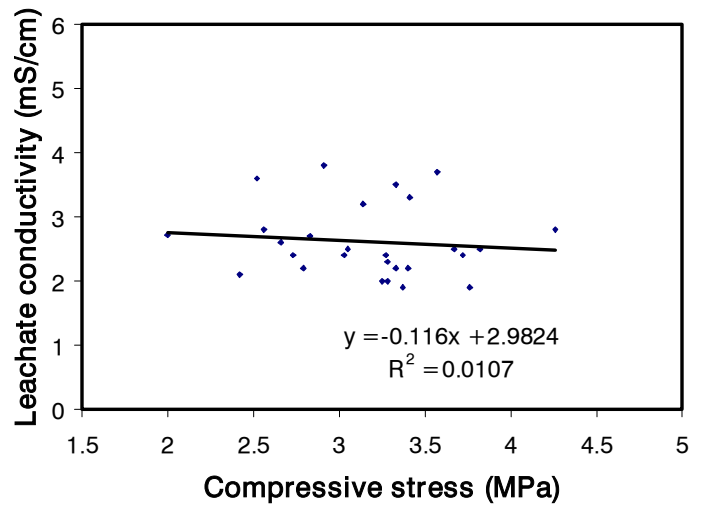

Figure 5. Relationship of Na leachability versus compressive strength.

the stronger samples may

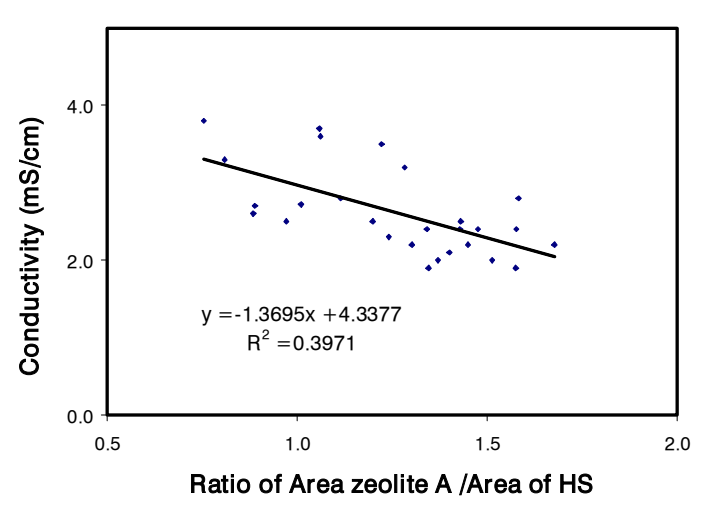

Figure 6. Relationship of $\mathrm{Na}$ leachability versus ratio of zeolite $\mathrm{A} / \mathrm{hydroxysodalite.}$

have lower leachabilities. It is also notable that the 1 and 7 day conductivities are nearly the same, illustrating the suitability of a 1 day test for scoping and other comparative statements.

\section{Characterization}

The crystalline phases present in the 27 blocks were also investigated using X-ray diffraction. The X-ray diffraction patterns of the samples are similar. Each contains a mix of zeolite A and hydroxysodalite. The ratios of the peak area of zeolite A at $\mathrm{d}(100)=1.23 \mathrm{~nm}$ and that of hydroxysodalite at $\mathrm{d}(110)=0.633 \mathrm{~nm}$ was calculated. The ratios are distributed in a small range between 0.8 and 1.7 , which also suggests that the sample is homogeneous. The correlation between this ratio and PCT conductivity is given in Figure 6. The data indicate that $\mathrm{Na}$ leachability is higher when the sample contains relatively larger amounts of hydroxysodalite. The results suggest that a high compressive strength and a high zeolite A content should provide the best performing hydroceramic waste form.

Solidifying a low $\mathrm{NO}_{\mathrm{x}}$ Waste: A Comparison of Options

Savannah River has removed Cs and Sr from a sample of Tank 44 SBW to make it possible to work with it in a shielded hood. As a result it is about one half as concentrated in $\mathrm{Na}$ as the original (Table 2). The simplified recipe supplied by Savannah River is given in Table 6 and its simulation is given in Table 7. Note however that the nitrate and nitrite concentrations are just about on the cusp between the two Types of SBW defined earlier. The moles of nitrate+nitrite divided by the total moles of sodium in the SBW is $\sim 20 \%$. For this reason two experiments were run and the results compared. In one case the hydroceramic was made using the solution itself without any pretreatement and in the second case the SBW was first calcined with sucrose and metakaolin to make a calcine that was then solidified using additional metakaolin plus $4 \mathrm{M} \mathrm{NaOH}$ binder. 
Table 6. Composition of Tank 44 SBW.

\begin{tabular}{ll}
\hline Ions present & Concentration (M) \\
\hline $\mathrm{Na}^{+}$ & 5.1 \\
$\mathrm{NO}_{3}^{-}$ & 0.5 \\
$\mathrm{NO}_{2}^{-}$ & 0.5 \\
$\mathrm{AlO}_{2}^{-}$ & 0.2 \\
$\mathrm{OH}^{-}$ & 4.5 \\
\hline
\end{tabular}

Table 7. Composition of Simulated Tank 44.

\begin{tabular}{llll}
\hline Composition & MW & M & g/L \\
\hline $\mathrm{CsNO}_{3}$ & 194.909 & 0.5 & 97.4545 \\
$\mathrm{KNO}_{2}$ & 85.107 & 0.1 & 8.5107 \\
$\mathrm{NaNO}_{2}$ & 69.000 & 0.4 & 27.6000 \\
$\mathrm{NaAlO}_{2}$ & 81.979 & 0.2 & 16.3958 \\
$\mathrm{NaOH}$ & 39.998 & 4.5 & 179.9910 \\
\hline
\end{tabular}

Metakaolinite was mixed with varying amounts of SBW directly, cured at $90^{\circ} \mathrm{C}$ and $190^{\circ} \mathrm{C}$ in a steam saturated atmosphere (Teflon-lined Parr bombs) for 24 hours. Mix proportions, crystalline phases observed in the hydroceramic, Na leachability as calculated using a 1 day unwashed sample PCT test, and a calculated value for the \% $\mathrm{Na}$ leached versus total $\mathrm{Na}$ content of the hydroceramic are given in Tables $8\left(90^{\circ} \mathrm{C}\right.$ cured $)$ and Table $9\left(190^{\circ} \mathrm{C}\right.$ cured). The higher curing temperature provides a slight improvement in leachability, but its implication would come at a very high price. Curing at $90^{\circ} \mathrm{C}$ can be in can in a warm room, curing at $190^{\circ} \mathrm{C}$ would have to be carried out in a steam/dry autoclave operating at 12-13 atmospheres pressure.

Table 8. Metakaolin mixed with different amounts of SBW and cured at $90^{\circ} \mathrm{C}$ for $24 \mathrm{hrs}$

\begin{tabular}{lllllll}
\hline Sample Number & $\# 1$ & $\# 2$ & $\# 3$ & $\# 4$ & $\# 5$ & $\# 6$ \\
\hline Metakaolin & $1 \mathrm{~g}$ & $1 \mathrm{~g}$ & $1 \mathrm{~g}$ & $1 \mathrm{~g}$ & $1 \mathrm{~g}$ & $1 \mathrm{~g}$ \\
SBW Simulant & $0.5 \mathrm{ml}$ & $1.0 \mathrm{ml}$ & $1.5 \mathrm{ml}$ & $2.0 \mathrm{ml}$ & $3.0 \mathrm{ml}$ & $3.5 \mathrm{ml}$ \\
Crystalline Phases & $\mathrm{Mk}$ & $\mathrm{A}$ & $\mathrm{A}$ & $\mathrm{HS}$ & $\mathrm{HS}$ & $\mathrm{HS}$ \\
Conductivity $(\mathrm{mS} / \mathrm{cm})$ & -- & 7.70 & 8.90 & 9.10 & -- & -- \\
\% total Na leached & -- & 10.6 & 8.9 & 7.4 & -- & -- \\
\hline
\end{tabular}

$\mathrm{Mk}=$ metakaolin, $\mathrm{A}=$ =zeolite $\mathrm{A}, \mathrm{HS}=$ hydroxysodalite, -- not analyzed

Table 9. Metakaolin mixed with different amounts of SBW and cured at $190^{\circ} \mathrm{C}$ for $24 \mathrm{hrs}$.

\begin{tabular}{llllll}
\hline Sample Number & $\# 1$ & $\# 2$ & $\# 3$ & $\# 4$ & $\# 5$ \\
\hline Metakaolin & $1 \mathrm{~g}$ & $1 \mathrm{~g}$ & $1 \mathrm{~g}$ & $1 \mathrm{~g}$ & $1 \mathrm{~g}$ \\
SBW Simulant & $0.5 \mathrm{ml}$ & $1.0 \mathrm{ml}$ & $1.5 \mathrm{ml}$ & $2.0 \mathrm{ml}$ & $3.0 \mathrm{ml}$ \\
Crystalline Phases & $\mathrm{Mk}+\mathrm{Q}$ & $\mathrm{Mk}+\mathrm{Q}+\mathrm{HS}$ & $\mathrm{MK}+\mathrm{Q}+\mathrm{HS}$ & $\mathrm{Q}+\mathrm{HS}+\mathrm{A}$ & $\mathrm{Q}+\mathrm{HS}+\mathrm{A}$ \\
Conductivity $(\mathrm{mS} / \mathrm{cm})$ & -- & 4.80 & 5.30 & 9.20 & -- \\
\% total Na leached & -- & 6.6 & 5.3 & 7.5 & --
\end{tabular}

$\mathrm{Mk}=$ metakaolin, $\mathrm{Q}=$ quartz, $\mathrm{HS}=$ hydroxysodalite, $\mathrm{A}=$ zeolite $\mathrm{A}$, -- not analyzed

As stated above, this SBW was also solidified after first calcining it with sucrose and metakaolinite at $525^{\circ} \mathrm{C}$ overnight. $38 \mathrm{~g}$ sugar $/ \mathrm{L}$ was added to the SBW simulant at the ratio of $38 \mathrm{~g} / \mathrm{mol} \mathrm{NO}_{3}+\mathrm{NO}_{2}$. In order to reduce the formation of sodium carbonate during calcination 79.3 $\mathrm{g}$ and $113.3 \mathrm{~g}$ metakaolin were also added to 2 different $100 \mathrm{~mL}$ aliquots of the SBW at the mole ratio of metakaolin: $\mathrm{Na}=0.7: 1$ and 1:1. These have been found to be the ratios that most favor the production of tectosilicate phases in the calcine. After slurrying the dry ingredients with the SBW, the slurry was dried at $90^{\circ} \mathrm{C}$ and then fired at $525^{\circ} \mathrm{C}$ for 10 hours. The resulting powders are referred to as calcines. Weight lost during firing, crystalline phase formation, conductivity measurements performed using a Modified PCT leaching test and the total \% $\mathrm{Na}$ leached for the two calcines studied are given in Table 10. 
Table 10. Leachability of two Simulated Savannah River Tank 44 SBW Calcines made with Metakaolin and Sucrose and Heated at $525^{\circ} \mathrm{C}$.

\begin{tabular}{lll}
\hline Sample Number & Calcine \#1 & Calcine \#2 \\
& $\mathrm{Mk}: \mathrm{Na}=0.7: 1$ & $\mathrm{Mk}: \mathrm{Na}=1.0: 1$ \\
\hline Weight lost during firing & $11.6 \%$ & $9.2 \%$ \\
Crystalline phase & Amorphous + Quartz & Amorphous + Quartz \\
Conductivity $(\mathrm{mS} / \mathrm{cm})$ & 7.10 & 5.10 \\
$\%$ total Na leached & 9.6 & 9.0 \\
\hline
\end{tabular}

It is concluded that the Na leachability of the directly solidified SBW and its calcined equivalent are approximately the same. The amount of sodium lost by each sample in terms of the total amount of sodium present in the samples suggests that approximately $5-10 \%$ of the total sodium present can be removed by leaching either type of sample at $90^{\circ} \mathrm{C}$ for 1 day. The calcine made from the SBW mixed with sucrose and metakaolinite and fired at $525^{\circ} \mathrm{C}$ overnight did not out perform the directly solidified SBW to such an extent as to warrant the cost of calcining it under pressure at higher temperatures. Note however that the calcine in question is a powder and in order to ship it off site it might have to be solidified. Once so solidified, using additional metakaolin and $4 \mathrm{M} \mathrm{NaOH}$ as a binder as described below, leachability improved significantly.

Monolithic hydroceramics were prepared from Calcines 1 and 2 (Table 10) by mixing $12 \mathrm{~g}$ calcine and $8 \mathrm{~g}$ metakaolin with $18 \mathrm{ml} 4 \mathrm{M} \mathrm{NaOH}$ to form a paste. The pastes were molded in 2 inch by 1 inch diameter of cylinder molds and then precured at $40^{\circ} \mathrm{C}$ in a $50 \%$ humidity chamber overnight. After demolding, the samples were cured at $90^{\circ}$ and $190^{\circ} \mathrm{C}$ in a steam saturated atmosphere (Teflon-lined Parr bombs) for 24 hours. The samples were characterized and tested as before. In addition phase composition, densities and compressive strengths were also determined. See Tables 12 and 13.

The percentages of $\mathrm{Na}$ leached from these monolithic solids are the lowest of the tested samples. Strengths are also adequate. The data suggest that a two step process will produce a

Table 12. Hydroceramic waste forms cured at $90^{\circ} \mathrm{C}$ for 24 hours

\begin{tabular}{lll}
\hline Sample & Monolith \#1 Mk:Na=0.7:1 & Monolith \#2 Mk:Na=1.0:1 \\
\hline Crystalline phase & Zeolite A & Zeolite A \\
density & 1.06 & 1.07 \\
Compressive strength $(\mathrm{mPa})$ & 3.21 & 3.07 \\
Conductivity $(\mathrm{mS} / \mathrm{cm})$ & 3.20 & 3.00 \\
\% total Na leached & 3.9 & 4.0 \\
\hline
\end{tabular}

Table 13. Hydroceramic waste forms cured at $190^{\circ} \mathrm{C}$ for 24 hours

\begin{tabular}{lll}
\hline Sample & Monolith \#1 Mk:Na=0.7:1 & Monolith \#2 Mk:Na=1.0:1 \\
\hline Crystalline phase & Analcime $+\mathrm{HS}$ & Zeolite A + HS \\
density & 1.05 & 1.06 \\
Compressive strength $(\mathrm{mPa})$ & 3.51 & 3.42 \\
Conductivity $(\mathrm{mS} / \mathrm{cm})$ & 2.10 & 1.10 \\
$\%$ total Na leached & 2.6 & 1.5 \\
\hline
\end{tabular}


much better waste form, but the fact remains that the single step process may in fact be sufficient to do the job in its own right. Waste specific testing will have to be carried out in order to show that this is true. If it is not, a two step process could be used instead.

\section{Optimization}

The following set of experiments was meant to determine the optimum calcination temperature for calcining high $\mathrm{NO}_{\mathrm{x}} \mathrm{SBW} /$ metakaolinite/sucrose mixtures. It was found that temperature plays a rather significant role up to a point after which further increases in calcination temperature cause only relatively small changes in leachability. The simulated SBW used in the experiments (Table 14) was based upon a recipe originally published by Jantzen ${ }^{13}$ that represents the composition of SBW in Hanford's Tank AN-107. The calcines were made by preblending the SBW simulant with metakaolinite and sucrose in the proper proportions needed to reduce nitrate and nitrite ions and form precursor tectosilicate phases. Sodium ion leachability was measured as a function of temperature, which suggested that the optimal (lower volatility and fuel costs, higher reactivity for later solidification with a hydroceramic binder) calcination temperature for this simulated SBW was $525^{\circ} \mathrm{C}$ overnight in air. The resulting calcines were powders but even so the data show that they have reasonably low leachability in their own right. Nevertheless, in order to store the calcines off site they may have to be solidified if current laws are not changed. This simulant is clearly a high $\mathrm{NO}_{\mathrm{x}}$ waste, $>25 \%$ of the sodium salts present are nitrite/nitrate based $(\mathrm{N} / \mathrm{Na}=0.48)$ and it contains a significant amount of carbonate as well $\left(\mathrm{N}+\mathrm{CO}_{3}^{-} / \mathrm{Na}=0.62\right)$. At this point in time high $\mathrm{NO}_{x}$ waste must be de nitrated/denitrited before it can be solidified. Calcining SBW in air or in a steam reformer produces sodium carbonate. Adding a reducing agent such as sucrose and a sodium "getter" able to tie up nascent $\mathrm{Na}$ ions as they form allows one to produce sodium aluminosilicates at temperatures ranging from $375-$ $675^{\circ} \mathrm{C}$ (zeolites at low temperatures, feldspathoids at higher temperatures) as described later. Steam reforming also produces the same type of material, but the phases are more nearly feldspathic than zeolitic. Calcination was carried out in the presence of a reducing agent added at a ratio of $38 \mathrm{~g}$ sucrose/mol $\mathrm{NO}_{3}+\mathrm{NO}_{2}(111 \mathrm{~g}$ sugar/L) and metakaolinite at a Mk:Na ratio of 0.7:1 $(1275 \mathrm{~g} / \mathrm{L})$ in order to tie up sodium ions as they formed. The aluminosilicates (calcined clay) reacted with the waste to form less soluble aluminosilicates. The slurry that formed after adding the sugar and calcined clay to the $\mathrm{AN}-107$ simulant was dried at $90^{\circ} \mathrm{C}$ and then $60 \mathrm{~g}$ portions of it were calcined at $375^{\circ}, 450^{\circ}, 525^{\circ}, 600^{\circ}$, and $675^{\circ} \mathrm{C}$ for 10 hours. See Table 15. The calcines were characterized. X-ray Diffraction (XRD) and scanning electron microscopy (SEM) were used to identify the crystalline phase and the morphology of the as-prepared materials. Theoretically, there are $45.1 \mathrm{wt} \%$ of $\mathrm{Al}_{2} \mathrm{O}_{3}$ and $54.1 \mathrm{wt} \%$ of $\mathrm{SiO}_{2}$ in pure metakaolinite. However, due to the presence of quartz impurities in the Troy clay, the composition of $\mathrm{SiO}_{2}$ is somewhat higher. X-ray diffraction patterns of the calcines show that the calcines are nearly devoid of crystalline components, they are dominated by an "amorphous hump" suggesting that they contain a mixture of poorly crystalline short range ordered aluminosilicates. Small amounts of muscovite and quartz which exist in original clay and small amount of hydroxyl sodalite were also detected. Over the range of calcination temperatures used, crystalline nepheline or nosean did not form. This is in contrast with Jantzen's reported findings for a similar waste stream that was steam reformed. ${ }^{13,14}$ The leachabilities and weight losses of the calcines during firing are given in Table 15. PCT tests for 1 and 7 days were also completed using an unwashed sample. The weight loss increased with calcination temperature, suggesting that increasing amounts of 
volatile fractions $\left(\mathrm{Na}_{2} \mathrm{O}\right)$ were lost with rising temperature. At higher temperatures one achieved a more nearly complete $\mathrm{NO}_{3}{ }^{-}$and $\mathrm{NO}_{2}{ }^{-}$reduction. Overall, $525^{\circ} \mathrm{C}$ seems optimum.

\begin{tabular}{c|c|c|c}
\hline Composition & $\mathrm{g} / \mathrm{L}$ & Composition & $\mathrm{g} / \mathrm{L}$ \\
\hline $\mathrm{Al}\left(\mathrm{NO}_{3}\right)_{3} \cdot 9 \mathrm{H}_{2} \mathrm{O}$ & 121.1723 & $\mathrm{PbO}$ & 0.3172 \\
$\mathrm{Ca}\left(\mathrm{NO}_{3}\right)_{2} \cdot 4 \mathrm{H}_{2} \mathrm{O}$ & 2.5171 & $\mathrm{NaCl}$ & 2.2999 \\
$\mathrm{Na}_{2} \mathrm{Cr}_{2} \mathrm{O}_{7} \cdot 2 \mathrm{H}_{2} \mathrm{O}$ & 0.6532 & $\mathrm{NaF}$ & 5.5596 \\
$\mathrm{CsNO}_{3}$ & 0.0157 & $\mathrm{Na}_{2} \mathrm{HPO}_{4}$ & 4.0852 \\
$\mathrm{Fe}\left(\mathrm{NO}_{3}\right)_{3} \cdot 9 \mathrm{H}_{2} \mathrm{O}$ & 15.0138 & $\mathrm{Na}_{2} \mathrm{SO}_{4}$ & 11.7463 \\
$\mathrm{KOH}$ & 2.0483 & $\mathrm{NaNO}_{2}$ & 69.0892 \\
$\mathrm{La} \mathrm{O}_{3}$ & 0.0307 & $\mathrm{NaNO}_{3}$ & 155.6883 \\
$\mathrm{NaOH}$ & 105.9035 & $\mathrm{Na}_{2} \mathrm{CO}_{3}$ & 123.0559 \\
$\mathrm{NiO}$ & 0.4637 & & \\
\hline
\end{tabular}

Table 14. Ingredients used to make the $\mathrm{AN}$ 107 stimulant. The total moles of nitrate and nitrite anions are $2.93 \mathrm{~mol} / \mathrm{l}$. The total Na concentration is 8.2 $\mathrm{mol} / \mathrm{l}$. The total ash content using a major oxide basis is $291.7 \mathrm{~g} / \mathrm{l}$.

Table 15. Weight lost of the calcines and conductivity of the PCT for the calcines with different calcination temperatures.

\begin{tabular}{llllll}
\hline Cal. Temp & $375^{\circ} \mathrm{C}$ & $450^{\circ} \mathrm{C}$ & $525^{\circ} \mathrm{C}$ & $600^{\circ} \mathrm{C}$ & $675^{\circ} \mathrm{C}$ \\
\hline Weight lost & $13.3 \%$ & $15.0 \%$ & $15.8 \%$ & $16.7 \%$ & $17.5 \%$ \\
1 day leach $(\mathrm{mS} / \mathrm{cm})$ & 9.80 & 6.40 & 4.20 & 3.90 & 3.60 \\
7 days leach $(\mathrm{mS} / \mathrm{cm})$ & 10.30 & 6.70 & 5.10 & 4.80 & 3.80 \\
\hline
\end{tabular}

The results of elemental analyses of the leachates are given in Table 16. It is evident that the leachability of the calcines is dependent on the calcination temperature. The major elements in AN-107 are sodium and aluminum. The concentration of aluminum shows little dependence on the calcination temperature, while the concentration of sodium decreases with the increase of calcination temperature and almost levels off when the calcination temperature is higher than $525{ }^{\circ} \mathrm{C}$. Potassium and cesium exhibit the same trend as sodium, but, since the concentration of

Table 16. Elemental composition $(\mathrm{mg} / \mathrm{L})$ of the PCT filtrate for five Calcines ( 1 and 7 days).

\begin{tabular}{lllllllllll}
\hline Composition & \multicolumn{3}{c}{$375^{\circ} \mathrm{C}$} & \multicolumn{3}{c}{$450^{\circ} \mathrm{C}$} & \multicolumn{3}{c}{$525^{\circ} \mathrm{C}$} & \multicolumn{3}{c}{$600^{\circ} \mathrm{C}$} & \multicolumn{3}{c}{$675^{\circ} \mathrm{C}$} \\
& $1 \mathrm{~d}^{\mathrm{a}}$ & $7 \mathrm{~d}^{\mathrm{b}}$ & $1 \mathrm{~d}$ & $7 \mathrm{~d}$ & $1 \mathrm{~d}$ & $7 \mathrm{~d}$ & $1 \mathrm{~d}$ & $7 \mathrm{~d}$ & $1 \mathrm{~d}$ & $7 \mathrm{~d}$ \\
\hline $\mathrm{Al}$ & 460.0 & 510.0 & 450.0 & 470.0 & 410.0 & 450.0 & 410.0 & 490.0 & 360.0 & 400.0 \\
$\mathrm{Ca}$ & $<0.05$ & $<0.05$ & $<0.05$ & $<0.05$ & 0.1 & $<0.05$ & 0.3 & 0.3 & 0.8 & 0.5 \\
$\mathrm{Cr}$ & 8.6 & 8.6 & 6.9 & 6.9 & 5.0 & 5.7 & 4.1 & 4.4 & 2.4 & 2.9 \\
$\mathrm{Cs}$ & $<0.2$ & 1.5 & $<0.2$ & $<0.2$ & 0.4 & $<0.2$ & 2.7 & $<0.2$ & $<0.2$ & $<0.2$ \\
$\mathrm{Fe}$ & 0.1 & 0.2 & 0.5 & 0.7 & 1.6 & 0.9 & 2.7 & 2.1 & 4.2 & 2.7 \\
$\mathrm{~K}$ & 6.3 & 8.1 & 1.7 & 1.7 & 0.6 & 1.7 & 0.6 & 1.7 & $<0.2$ & $<0.2$ \\
$\mathrm{La}$ & $<0.2$ & $<0.2$ & $<0.2$ & $<0.2$ & $<0.2$ & $<0.2$ & $<0.2$ & $<0.2$ & $<0.2$ & $<0.2$ \\
$\mathrm{Mg}$ & $<0.05$ & $<0.05$ & $<0.05$ & $<0.05$ & $<0.05$ & $<0.05$ & 0.3 & 0.2 & 0.7 & 0.4 \\
$\mathrm{Na}$ & 2560.0 & 2650.0 & 1500.0 & 1660.0 & 970.0 & 1200.0 & 860.0 & 1100.0 & 730.0 & 850.0 \\
$\mathrm{Ni}$ & $<0.2$ & $<0.2$ & $<0.2$ & $<0.2$ & $<0.2$ & $<0.2$ & $<0.2$ & $<0.2$ & $<0.2$ & $<0.2$ \\
$\mathrm{P}$ & 2.9 & 1.2 & 3.5 & 1.7 & 4.6 & 3.5 & 5.2 & 5.8 & 4.6 & 4.6 \\
$\mathrm{Si}$ & 27.0 & 26.0 & 34.0 & 26.0 & 37.0 & 28.0 & 34.8 & 41.0 & 58.0 & 27.0 \\
$\mathrm{Ti}$ & 0.1 & 0.1 & 0.1 & 0.3 & 0.3 & 0.3 & 0.3 & 0.6 & 0.6 & 0.6 \\
& & & & & & & & & & \\
$\mathrm{~F}$ & 8.1 & 10.5 & 7.5 & 8.6 & 10.0 & 15.8 & 4.2 & 15.3 & 2.8 & 11.7 \\
\hline
\end{tabular}




\begin{tabular}{lllllllllll}
\hline $\mathrm{Cl}$ & 64.0 & 62.0 & 48.0 & 54.0 & 33.0 & 45.0 & 13.2 & 28.0 & 0.9 & 4.7 \\
$\mathrm{NO}_{2}$ & 24.2 & 38.0 & 6.9 & 19.7 & 3.8 & 6.9 & 4.1 & 6.1 & 0.7 & 2.8 \\
$\mathrm{NO}_{3}$ & 2270.0 & 2190.0 & 750.0 & 940.0 & 255.0 & 460.0 & 46.0 & 130.0 & 3.9 & 14.9 \\
$\mathrm{PO}_{4}$ & 1.3 & $<0.2$ & 3.3 & 0.3 & 4.5 & 2.3 & 7.2 & 4.1 & 4.9 & 6.1 \\
$\mathrm{SO}_{4}$ & 330.0 & 330.0 & 270.0 & 295.0 & 215.0 & 225.0 & 215.0 & 225.0 & 140.0 & 160.0
\end{tabular}

a. $1 \mathrm{~d}$ means that PCT experiment was 1 day long.

b. $7 \mathrm{~d}$ means that PCT experiment was 7 days long.

cesium in the leachate is close to the detection limit of the ICP instrument, the temperature dependence of cesium is not as clear. The alkaline earth ions exhibit the opposite temperature dependence. Although the alkaline earth compounds are also effectively solidified upon calcination, the concentrations of alkaline earth ions in the leachate increase with increasing calcination temperature. A significant increase in their concentration occurs when the calcination temperature is greater than $525^{\circ} \mathrm{C}$. Iron and titanium have the same dependence on calcination temperature as the alkaline earth elements, while the concentration of chromium in the leachate decreases with the increasing temperature. The concentration of nickel and lanthanum are below the detection limit. Not surprising since they were not deliberately added. The leachability of Si shows little dependence on calcination temperature. For the anions, the concentrations of all the species decrease except phosphate and

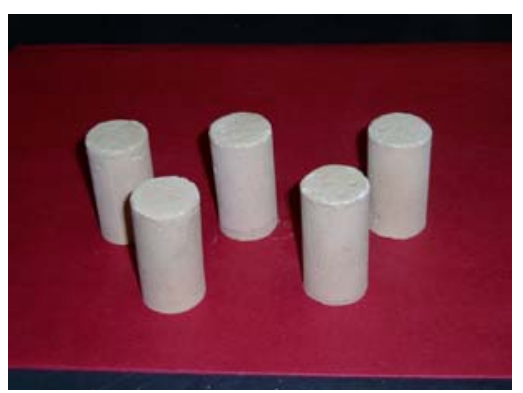

Figure 7. Hydroceramic monoliths produced from the calcines. fluoride, because they either decompose or are reduced or vaporize at higher temperatures. Phosphate and fluoride are the less volatile species. The rate of nitrate and nitrite reduction becomes slower when calcination is carried out much above $525^{\circ} \mathrm{C}$. Based on the observation that PCT based leachates experience minimum values when calcination is carried out at $\sim 525^{\circ} \mathrm{C}^{12}$, it is proposed that $525^{\circ} \mathrm{C}$ be used to prepare calcines from high $\mathrm{NO}_{\mathrm{x}}$ SBW.

Monolith hydroceramics were prepared from the five calcines in order to determine the benefit of making a monolithic hydroceramic from them. The hydroceramic is acting like a binder in this instance and as such may be useful for solidifying IEENL's existing calcines. The solids were made by mixing $12 \mathrm{~g}$ calcine and $8 \mathrm{~g}$ calcined clay with $18 \mathrm{ml} 4 \mathrm{M} \mathrm{NaOH}$ to form a paste. The pastes were molded in 2 inch by 1 inch diameter cylinder molds and then precured at $40^{\circ} \mathrm{C}$ in a $50 \%$ humidity chamber overnight. After demolding, the samples were cured at $90^{\circ} \mathrm{C}$ in a steam saturated atmosphere (Teflon-lined Parr bombs) for 24 hours. See Figure 7. Density, compressive strength and preliminary leach data (conductivity) for the cured solids are given in Table 17.

The phases in the monoliths were identified by X-ray diffraction. Patterns are given in Figure 8. The main crystalline phases are zeolite A, hydroxysodalite and quartz. Zeolite A, having the general formula of $\left[\mathrm{Na}_{12}\left[\mathrm{Al}_{12} \mathrm{Si}_{12} \mathrm{O}_{48}\right] \cdot 27 \mathrm{H}_{2} \mathrm{O}\right]$, consists of sodalite cages connected at the four-ring position to create double four ring connections. This causes zeolite A to have two different cages sizes. The first is a smaller sodalite cage accessible through the 6-ring opening that has a diameter of $0.22 \mathrm{~nm}$. The internal cage diameter is $0.66 \mathrm{~nm}$. The second cage is a larger supercage accessible through a 8-ring opening with a diameter of $0.41 \mathrm{~nm}$. The supercage internal diameter is $1.14 \mathrm{~nm}$. The ion in the zeolite is normally $\mathrm{Na}$, but the large cage can accomodate larger cations, such as $\mathrm{Cs}^{+}$and $\mathrm{NH}_{4}{ }^{+}$. Studies show that zeolite $\mathrm{A}$ has cation 
selectivity for Cs while hydroxysodalite does not. (Bao, Personal communication). Cs and Sr are HLW fractions of low activity sodium bearing waste and as such should be removed prior to

Table 17. Density, Compressive Strength and PCT Leachability of HC Samples made with listed Calcines, additional Metakaolinite and 4M NaOH Solution and Cured at $90^{\circ} \mathrm{C}$.

\begin{tabular}{llllll}
\hline Calcination Temperature & $375^{\circ} \mathrm{C}$ & $450{ }^{\circ} \mathrm{C}$ & $525{ }^{\circ} \mathrm{C}$ & $600{ }^{\circ} \mathrm{C}$ & $675^{\circ} \mathrm{C}$ \\
\hline Density $\left(\mathrm{g} / \mathrm{cm}^{3}\right)$ & 1.09 & 1.08 & 1.12 & 1.07 & 1.08 \\
Compressive $(\mathrm{MPa})$ & 3.58 & 3.52 & 3.54 & 3.04 & 4.07 \\
1 day leach $(\mathrm{mS} / \mathrm{cm})$ & 4.20 & 4.10 & 3.60 & 4.40 & 4.90 \\
7 days leach $(\mathrm{mS} / \mathrm{cm})$ & 4.30 & 4.20 & 3.70 & 4.70 & 5.40 \\
\hline
\end{tabular}

making Saltstone. A hydroceramic binder is better suited for solidifying low activity SBW directly because the $\mathrm{Cs}$ and $\mathrm{Sr}$ will become part of the zeolite structure. Therefore, using a binder that maximizes the formation of zeolite A would serve two purposes. It would encapsulate the calcines and also tie up stray ions emanating from the calcines should they be exposed to water during long term storage. When considering the synthesis conditions that favor zeolite A formation, it seems that, the process of precuring the samples at $40^{\circ} \mathrm{C}$ in a $50 \%$ humidity chamber before demolding and final curing at $90^{\circ} \mathrm{C}$ introduces low temperature precursor phases

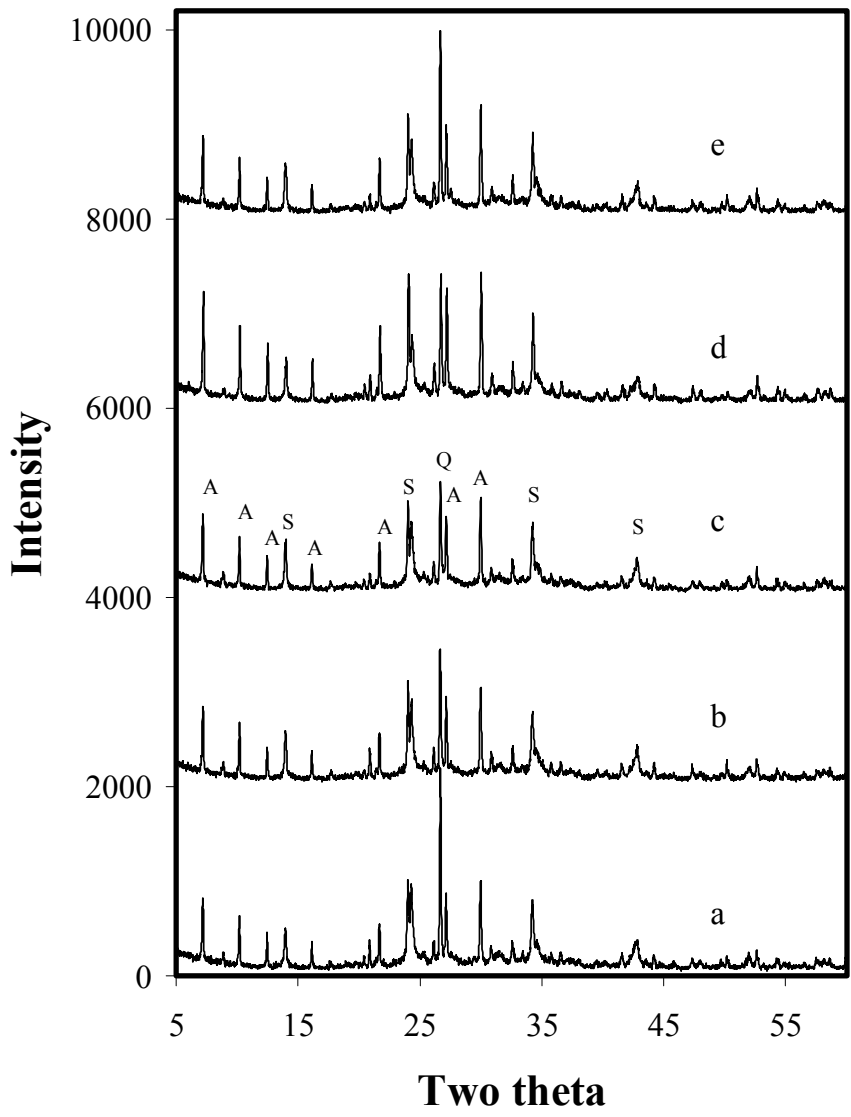
that eventually crystallize as zeolite A. Low intensity zeolite A peaks have been found in XRD patterns for the sample after precuring. Though the intensity of the zeolite A peak is low, the precursor zeolite phases can act as the seeds for the further crystallization. This may be one of the reasons that zeolite A forms during the final hydrothermal treatment in our experiments.

The morphology of the resulting hydroceramics was examined by SEM. The images in Figure 9 clearly indicate the existence of ill-defined cubic and spherical phases in the hydroceramic made from the $375^{\circ} \mathrm{C}$ calcine (view a) versus very crystalline appearing morphologies in the other samples (views b-e). When calcination temperatures reach or exceed $425^{\circ} \mathrm{C}$, well crystallized zeolite $\mathrm{A}$ and hydroxysodalite crystals form. Higher calcination temperatures cause larger precursor crystals to form that grow

Figure 8. X-ray diffraction patterns of hydroceramics prepared from the Calcines in Table 14 mixed with additional metakaolinite and $4 \mathrm{M} \mathrm{NaOH}$ and cured at $90^{\circ} \mathrm{C}$. Symbols represent the calcination temperature of the calcine in the hydroceramic.: a. $375^{\circ} \mathrm{C}$, b. $450^{\circ} \mathrm{C}$, c. $525^{\circ} \mathrm{C}$, d. $600^{\circ} \mathrm{C}$, e. $675^{\circ} \mathrm{C}$ 

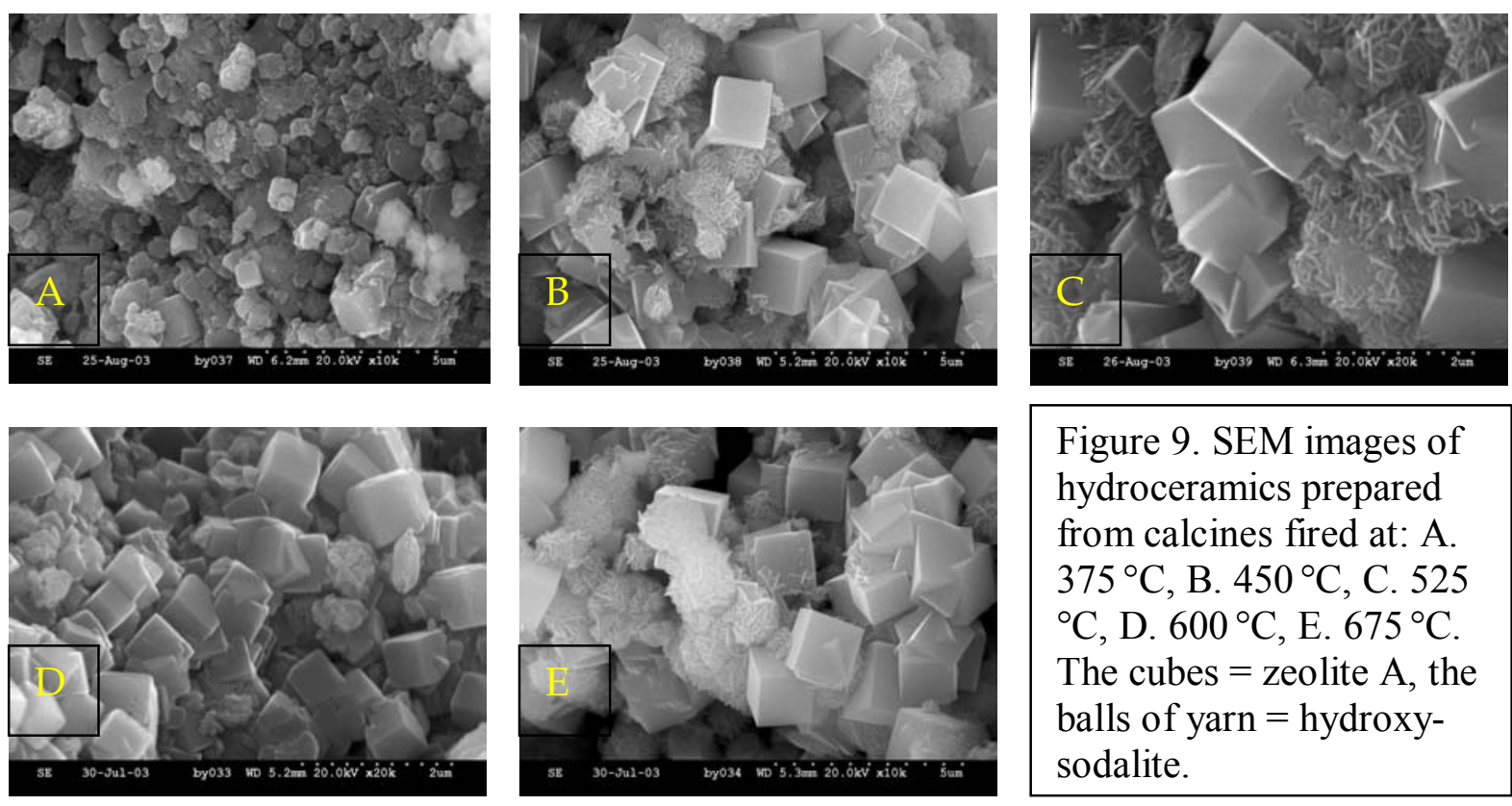

Figure 9. SEM images of hydroceramics prepared from calcines fired at: A. $375^{\circ} \mathrm{C}$, B. $450{ }^{\circ} \mathrm{C}$, C. 525 ${ }^{\circ} \mathrm{C}, \mathrm{D} .600^{\circ} \mathrm{C}, \mathrm{E} .675^{\circ} \mathrm{C}$. The cubes $=$ zeolite $\mathrm{A}$, the balls of yarn $=$ hydroxysodalite.

during monolith production. Zeolite A forms cubic crystals, and hydroxysodalite takes on a smaller "balls of yarn" apperance. The existence of a range of crystallite sizes may be an advantage, because smaller crystals can occupy the open spaces present in hydroceramics, reducing the rate of transport of ions (radionuclides or other cations and anions) in or out of the structure. Zeolite A also appears to inter-grow with itself and hydroxysodalite (views b-e). The interlocking crystalline structure will also impart high strength to the monolith, which is important if and when the hydroceramic is shipped off site.

The optimum firing temperature for the calcines used to make the monoliths in Figure 7 was further evaluated by leaching the hydroceramic monoliths using a 1 and 7 day PCT test. In the past it has been observed that $525^{\circ} \mathrm{C}$ calcines are reactive and have acceptably low leachabilites. The conductivities of the leachates for the monoliths are given in Table 17. Conductivities for the hydroceramic monoliths are much lower than those for the equivalent calcines (Table 15) illustrating the fact that a hydroceramic is a better waste form than the calcines. However, unlike the calcines that continue to perform better (lower $\mathrm{Na}$ leachability) as the calcination temperature rises, the conductivity of the leachates for the calcines solidified with metakaolinite and $4 \mathrm{M} \mathrm{NaOH}$ only worsen with higher calcination temperatures. The data also suggest that a minimum occurs when the $\mathrm{SBW}$ is calcined at $525^{\circ} \mathrm{C}$. This is consistent with SEM observations that the $525^{\circ} \mathrm{C}$ hydroceramic has the largest amount of intergrowth and the least amount of porosity.

The elemental analyses of the PCT leachates for these same samples are given in Table 18. The concentration of the main components in the leachate $\left(\mathrm{Na}^{+}, \mathrm{Al}^{3+}, \mathrm{NO}_{3}{ }^{-}\right.$and $\left.\mathrm{SO}_{4}{ }^{2-}\right)$ are much lower for the monoliths than they are for the calcines they contain (Table 16) indicating that a hydroceramic binder will either further encapsulate or chemically bind ions to a greater degree than the raw calcines. The concentration of other minor components $\left(\mathrm{Cl}, \mathrm{NO}_{2}{ }^{-}, \mathrm{Cr}\right.$, etc. $)$ is also further reduced by the formation of hydroceramics. The concentration of sodium is at a minimum in the $525^{\circ} \mathrm{C}$ calcine containing hydroceramic, which is in keeping with the aforementioned lowest value experienced by this same sample. Other species $\left(\mathrm{K}, \mathrm{P}, \mathrm{Si}, \& \mathrm{SO}_{4}{ }^{2-}\right)$ 
Table 18. Elemental Analyses of the PCT Solution for Hydroceramics made with the Listed Calcines (mg/L)

\begin{tabular}{|c|c|c|c|c|c|c|c|c|c|c|}
\hline \multirow[t]{2}{*}{ Composition } & \multicolumn{2}{|l|}{$375^{\circ} \mathrm{C}$} & \multicolumn{2}{|l|}{$450^{\circ} \mathrm{C}$} & \multicolumn{2}{|l|}{$525^{\circ} \mathrm{C}$} & \multicolumn{2}{|l|}{$600^{\circ} \mathrm{C}$} & \multicolumn{2}{|l|}{$675^{\circ} \mathrm{C}$} \\
\hline & $1 \mathrm{~d}^{\mathrm{a}}$ & $7 \mathrm{~d}^{\mathrm{b}}$ & $1 \mathrm{~d}$ & $7 \mathrm{~d}$ & $1 \mathrm{~d}$ & $7 \mathrm{~d}$ & $1 \mathrm{~d}$ & $7 \mathrm{~d}$ & $1 \mathrm{~d}$ & $7 \mathrm{~d}$ \\
\hline $\mathrm{Al}$ & 100.0 & 175.0 & 37.0 & 48.0 & 110.0 & 125.0 & 29.0 & 31.0 & 20.0 & 22.0 \\
\hline $\mathrm{Ca}$ & 0.2 & $<0.05$ & 0.2 & 0.2 & 0.3 & $<0.05$ & $<0.05$ & $<0.05$ & $<0.05$ & $<0.05$ \\
\hline $\mathrm{Cr}$ & 0.2 & 0.3 & 0.4 & 0.5 & 0.3 & 0.4 & 0.2 & 0.6 & 0.2 & 1.0 \\
\hline Cs & $<0.2$ & 0.3 & 0.4 & $<0.2$ & 0.5 & 0.5 & $<0.2$ & $<0.2$ & $<0.2$ & $<0.2$ \\
\hline $\mathrm{Fe}$ & 3.6 & 0.5 & 4.3 & 1.4 & 5.2 & 0.7 & 1.3 & 0.6 & 1.3 & 0.3 \\
\hline $\mathrm{K}$ & 6.3 & 6.9 & 6.3 & 7.5 & 5.8 & 5.2 & 9.2 & 8.6 & 9.2 & 10.4 \\
\hline $\mathrm{La}$ & $<0.2$ & $<0.2$ & $<0.2$ & $<0.2$ & $<0.2$ & $<0.2$ & $<0.2$ & $<0.2$ & $<0.2$ & $<0.2$ \\
\hline $\mathrm{Mg}$ & 0.6 & $<0.05$ & 0.6 & 0.2 & 0.8 & $<0.05$ & 0.2 & $<0.05$ & 0.3 & $<0.05$ \\
\hline $\mathrm{Na}$ & 1090.0 & 1070.0 & 1020.0 & 1040.0 & 780.0 & 800.0 & 1120.0 & 1180.0 & 1220.0 & 1350.0 \\
\hline $\mathrm{Ni}$ & $<0.2$ & $<0.2$ & $<0.2$ & $<0.2$ & $<0.2$ & $<0.2$ & $<0.2$ & $<0.2$ & $<0.2$ & $<0.2$ \\
\hline $\mathrm{P}$ & 6.9 & 5.2 & 8.1 & 7.5 & 5.8 & 4.6 & 8.6 & 5.8 & 6.9 & 6.9 \\
\hline $\mathrm{Si}$ & 56.0 & 47.0 & 90.0 & 69.0 & 80.0 & 58.0 & 100.0 & 69.0 & 130.0 & 105.0 \\
\hline $\mathrm{Ti}$ & 1.0 & 0.3 & 1.1 & 0.6 & 1.2 & 0.3 & 0.6 & 0.4 & 0.8 & 0.3 \\
\hline $\mathrm{F}$ & 41.0 & 40.0 & 53.0 & 59.0 & 66.0 & 49.0 & 48.0 & 59.0 & 47.0 & 45.0 \\
\hline $\mathrm{Cl}$ & 34.0 & 33.0 & 25.1 & 25.0 & 17.6 & 19.1 & 13.5 & 15.2 & 8.0 & 9.7 \\
\hline $\mathrm{NO} 2$ & 17.3 & 20.7 & 8.6 & 6.9 & 2.8 & 2.1 & 3.1 & 2.4 & 3.8 & 3.8 \\
\hline NO3 & 370.0 & 470.0 & 175.0 & 195.0 & 85.0 & 95.0 & 40.0 & 90.0 & 20.6 & 30.0 \\
\hline PO4 & 11.7 & 7.8 & 14.8 & 13.0 & 7.0 & 7.1 & 14.2 & 10.2 & 12.9 & 12.0 \\
\hline SO4 & 13.7 & 15.1 & 8.8 & 11.5 & 4.6 & 5.9 & 6.2 & 8.3 & 7.4 & 9.9 \\
\hline
\end{tabular}

a. $1 \mathrm{~d}$ means that PCT experiment was performed in 1 day

b. $7 \mathrm{~d}$ means that PCT experiment was performed in 7 days

also appear to have the lowest concentration in the leachate for the $525^{\circ} \mathrm{C}$. However, the concentration of $\mathrm{F}^{-}, \mathrm{PO}_{4}{ }^{3-}, \mathrm{Fe}$, and $\mathrm{Si}$ in the leachate from this hydroceramic is higher than those of the other calcines. At this time, the reason for the behavior of these particular ions is unknown. Also the effect of calcination temperature

There are several possible ways that the various nuclides can be immobilized in a hydroceramic waste form: surface adsorption, trapped in structural voids, occupy a lattice site, and via cation exchange. There are several possible mechanisms for the leaching of the nuclides: desorption, dissolution and diffusion. Hydroceramics have a zeolitic structure. They are relatively insoluble, much more than Portland cement. Zeolites are also good adsorbents. When making a hydroceramic by direct mixing with low activity low $\mathrm{NO}_{\mathrm{x}} \mathrm{SBW}$, the zeolites that form will preferentially encapsulate larger ions or ions with a higher charge than sodium. Nuclides can be incorporated in the zeolite cages. Once so encapsulated ion mobility could be hindered by the sizes of the openings in the zeolite structures that form. Cation exchange is also a well-known phenomena for zeolites. Literature results show that zeolites have selective cation exchange properties for $\mathrm{Cs}$ and $\mathrm{Sr}$ which are present in small amounts in SBW. A potential use for this property would be the use of a low $\mathrm{NO}_{\mathrm{x}}$ directly solidified SBW as a tank fill material. In this case secondary sources of these ions such as in empty tanks could be attracted and held by the zeolite in the hydroceramic. Many zeolites are also very stable, which is important for the longterm storage and isolation of these long lived radionuclides. Metamict damage of hydroceramics is also expected to be minor. The alteration of radionuclides to daughter products may not have as great an effect in a zeolite because there is latitude in space in the cages and channels which 
can accommodate changes in size without dramatic effects as in glass or crystalline waste forms. Furthermore, the thermal study of the stability of zeolite A shows that it can be fired at temperature around $1000^{\circ} \mathrm{C}$ to produce a ceramic if necessary.

A hydroceramic produced either by direct solidification of SBW with metakaolinite or through the use of a hydroceramic binder for existing calcines are promising ways to solidify all SBW. The leachability of zeolitic hydroceramics is significantly lower than that of the calcines. XRD, SEM, and leachability experiments demonstrated that the optimized calcination temperature for the preparation of calcines and zeolitic hydroceramics is $525^{\circ} \mathrm{C}$. Under these conditions, the calcine and hydroceramic have lowest leachability. The formation of zeolitic phases and their intergrowth are important for the overall performance of the hydroceramic waste form.

\section{Binder Experiments}

In this set of experiments an optimized Hanford calcine was solidified using both a hydroceramic binder and a conventional Portland cement grout. The calcine was prepared from the Table 14 simulant by mixing it with sucrose and metakaolinite at the weight ratio 20:2.5:11.9 which produced a slurry with the consistency of mud. After drying at $90^{\circ} \mathrm{C}$ for 24 hours, the dried material was calcined at $525^{\circ} \mathrm{C}$ for 18 hours. The calcine was granular and the X-ray diffraction pattern suggested that it was mainly X-ray amorphous with an amorphous hump centered at a location suggesting that it contains network structured phases. A chemical analysis of this type of calcine suggests that its nitrate and nitrite content are quite low $(<1 \mathrm{wt} \%)$ but carbonate still weighs in at $\sim 8 \mathrm{wt} \% .{ }^{21}$ As an aside, it is of interest to mention at this point that the calcine in question contains almost the identical raw materials used by Westinghouse in its SBW reforming trials run at $725^{\circ} \mathrm{C}$ in a Studsvik steam reformer. ${ }^{13,14}$ Other differences related to temperature are improved crystallinity and lower leachability, but in principle the end product is the same as the calcined SBW we have been studying for 6 years. The DOE has recognized the merits of making hydroceramic waste forms from SBW and is pushing forward with experiments (current extension of DOE grant to Penn State under Office of Science) and on site demonstrations of steam reforming both off and on site.

Should either technology be adopted, the end product will eventually have to be solidified and transported to a repository of some sort - be it Yucca Mountain or some other site. In order to make the waste "road ready" it will have to be solidified. Here we report the results of an experiment in which the Hanford calcine described above was solidified using metakaolinite and a variety of solutions ranging from water to $10 \mathrm{M} \mathrm{NaOH}$ solutions.

Table 19 gives the mechanical and phase properties of a set of hydroceramics made from the Hanford calcine. Different amounts of various molar $\mathrm{NaOH}$ solutions were used to make the pastes that were then cured at $90^{\circ}$ and $190^{\circ} \mathrm{C}$. It is notable that strength development is adequate for all of the $\mathrm{NaOH}$ containing samples and phases that developed include zeolite $\mathrm{A}$ and hydroxysodalite. Table 20 provides insight into the 1 and 7 day PCT leach performance of these same samples. The samples made with $4 \mathrm{M} \mathrm{NaOH}$ had the lowest $\mathrm{Na}$ loss as percentage $\mathrm{Na}$ in the sample.

\footnotetext{
${ }^{21}$ Krishnamurthy, N., Zeolitic Hydroceramics for Sodium Bearing Nuclear Wastes, a M.S. Thesis in Environmental Engineering, The Pennsylvania State University, December 2001 (2001). 2001
} 
Table 19. Crystalline Phases and Compressive Strengths of Hydroceramics made from Hanford Calcine, Metakaolin and various Solutions, Cured at $90^{\circ} \& 190^{\circ} \mathrm{C}$ for $24 \mathrm{hrs}$.

\begin{tabular}{c|c|c|c|c|c|c|c|c}
\hline $\begin{array}{c}5 \mathrm{~g} \text { Solids } \\
\text { Mixed with } \\
\begin{array}{c}4.5 \mathrm{~mL} \text { of } \\
\text { Solution } \\
\text { below }\end{array}\end{array}$ & $\begin{array}{c}\text { Total } \\
\mathrm{Mol} \\
\mathrm{Si} / \mathrm{Na}\end{array}$ & $\begin{array}{c}\text { TotalM } \\
\text { ol } \\
\mathrm{Al} / \mathrm{Na}\end{array}$ & $\begin{array}{c}\text { Crystalline } \\
\text { Phases } \\
\text { Present }\end{array}$ & $\begin{array}{c}\text { Green } \\
\text { Strength } \\
(\mathrm{MPa})\end{array}$ & $\begin{array}{c}\text { Cured } \\
\text { Strength } \\
(\mathrm{MPa})\end{array}$ & $\begin{array}{c}\text { Crystalline } \\
\text { Phases } \\
\text { Present }\end{array}$ & $\begin{array}{c}\text { Green } \\
\text { Strength } \\
(\mathrm{MPa})\end{array}$ & $\begin{array}{c}\text { Cured } \\
\text { Strength } \\
(\mathrm{MPa})\end{array}$ \\
\hline $\mathrm{H}_{2} \mathrm{O}$ & 2.689 & 2.103 & $\mathrm{Mk}$ & 0.21 & 0.21 & $\mathrm{Mk}$ & 0.21 & 0.21 \\
$2 \mathrm{M} \mathrm{NaOH}$ & 1.689 & 1.321 & $\mathrm{~A}$ & 0.27 & 2.37 & $\mathrm{~A}$ & 0.72 & 4.20 \\
$4 \mathrm{M} \mathrm{NaOH}$ & 1.231 & 0.963 & $\mathrm{~A}$ & 2.13 & 3.55 & $\mathrm{~A}$ & 2.32 & 4.00 \\
$6 \mathrm{M} \mathrm{NaOH}$ & 0.969 & 0.758 & $\mathrm{~A}+\mathrm{HS}$ & 5.27 & 6.34 & A+HS & 4.80 & 4.56 \\
$8 \mathrm{M} \mathrm{NaOH}$ & 0.799 & 0.624 & $\mathrm{HS}$ & 2.54 & 6.13 & HS & 5.45 & 4.48 \\
$10 \mathrm{MNaOH}$ & 0.679 & 0.531 & HS & 1.45 & 3.96 & HS & 4.56 & 4.20 \\
\hline
\end{tabular}

Tables 21 and 22 contain data for the same Hanford calcine but this time it was solidified with a Portland cement binder and various $\mathrm{NaOH}$ solutions having concentrations ranging from $0-10 \mathrm{M}$. Strengths are similar but phase formation and leachability are dramatically different. The percentage $\mathrm{Na}$ leached is at best roughly 10 times as high as the hydroceramic.

Table 20. Leachability of Table 19 Hydroceramics made with Metakaolin Binder.

\begin{tabular}{|c|c|c|c|c|c|c|c|c|}
\hline \multirow{2}{*}{$\begin{array}{l}\text { Total mol } \\
\text { of } \mathrm{Na} \text { in } \\
\text { PCT } \\
\text { samples }\end{array}$} & \multicolumn{4}{|c|}{$90^{\circ} \mathrm{C}$ Cured } & \multicolumn{4}{|c|}{$190^{\circ} \mathrm{C}$ Cured } \\
\hline & $\begin{array}{l}\text { Leach- } \\
\text { ability } \\
(\mathrm{mS} / \mathrm{cm})\end{array}$ & $\begin{array}{c}\mathrm{Na} \\
\text { Leached } \\
\left(\mathrm{mol} \cdot 10^{4}\right)\end{array}$ & $\begin{array}{c}\% \mathrm{Na} \\
\text { Leached }\end{array}$ & $\begin{array}{c}\mathrm{pH} \text { of } \\
\text { Leachate }\end{array}$ & $\begin{array}{l}\text { Leach- } \\
\text { ability } \\
(\mathrm{mS} / \mathrm{cm})\end{array}$ & $\begin{array}{c}\mathrm{Na} \\
\text { Leached } \\
\left(\mathrm{mol} \cdot 10^{4}\right)\end{array}$ & $\begin{array}{c}\% \mathrm{Na} \\
\text { Leached }\end{array}$ & $\begin{array}{c}\mathrm{pH} \text { of } \\
\text { Leachate }\end{array}$ \\
\hline 0.00304 & 3.3 .40 & 1.70 & 5.5 & 10.6 & 3.60 & 1.80 & 6.0 & 10.8 \\
\hline 0.00484 & 4.80 & 2.40 & 5.0 & 10.2 & 3.20 & 1.60 & 3.5 & 10.4 \\
\hline 0.00664 & 4.80 & 2.40 & 3.5 & 10.7 & 2.00 & 1.00 & 1.5 & 10.7 \\
\hline 0.00844 & 7.00 & 3.50 & 4.0 & 10.6 & 4.90 & 2.45 & 3.0 & 10.8 \\
\hline 0.01024 & 11.40 & 5.70 & 5.5 & 10.7 & 15.30 & 7.65 & 7.5 & 12.6 \\
\hline 0.01204 & $>100$ & -- & -- & 13.0 & $>100$ & -- & -- & 13.0 \\
\hline
\end{tabular}

-- not determined

We believe that the poor performance of the Portland cement binder in solidifying a sodium aluminosilicate (zeolitic) calcine was due to the reaction of the $\mathrm{Ca}(\mathrm{OH})_{2}$ produced during Portland cement hydration with the zeolite, a known pozzolanic reaction. The zeolitic phases in the calcine acted like pozzolans and reacted with the $\mathrm{Ca}(\mathrm{OH})_{2}$ in the Portland cement binder forming additional calcium silicate hydrate $(\mathrm{C}-\mathrm{S}-\mathrm{H})$. Typically $\mathrm{C}-\mathrm{S}-\mathrm{H}$ is unable to host large amounts of sodium ions in its structure, thus a majority of the sodium present in the zeolites became concentrated in the pore solution present in the Portland cement binder and readily entered the leachant during PCT testing. In this instance metakaolin mixed with $\mathrm{NaOH}$ proved to be a superior binder for solidification purposes. 
Table 21. Crystalline Phases and Compressive Strength of Waste Forms made from Hanford Calcine, Portland Cement and various Solutions, Cured at $90^{\circ} \& 190^{\circ} \mathrm{C}$ for $24 \mathrm{hrs}$.

\begin{tabular}{|c|c|c|c|c|c|c|c|c|}
\hline 5g Solids & & & \multicolumn{3}{|c|}{$90^{\circ} \mathrm{C}$ cured } & \multicolumn{3}{|c|}{$190^{\circ} \mathrm{C}$ cured } \\
\hline $\begin{array}{l}\text { Mixed with } \\
4.5 \mathrm{~mL} \text { of } \\
\text { Solution } \\
\text { below }\end{array}$ & $\begin{array}{c}\mathrm{Mol} \\
\mathrm{Si} / \mathrm{Na}\end{array}$ & $\begin{array}{c}\mathrm{Mol} \\
\mathrm{Al} / \mathrm{Na}\end{array}$ & $\begin{array}{c}\text { Crystalline } \\
\text { Phases } \\
\text { Present }\end{array}$ & $\begin{array}{c}\text { Green } \\
\text { Strength } \\
(\mathrm{MPa})\end{array}$ & $\begin{array}{c}\text { Cured } \\
\text { Strength } \\
(\mathrm{MPa})\end{array}$ & $\begin{array}{c}\text { Crystalline } \\
\text { phases } \\
\text { present }\end{array}$ & $\begin{array}{c}\text { Green } \\
\text { Strength } \\
(\mathrm{MPa})\end{array}$ & $\begin{array}{c}\text { Cured } \\
\text { Strength } \\
(\mathrm{MPa})\end{array}$ \\
\hline $\mathrm{H}_{2} \mathrm{O}$ & 1.877 & 1.291 & $\mathrm{C}_{3} \mathrm{~S}^{*}$ & 0.29 & 0.03 & $\mathrm{C}_{3} \mathrm{~S}$ & 0.34 & -- \\
\hline $2 \mathrm{M} \mathrm{NaOH}$ & 1.180 & 0.812 & $\mathrm{~A}+\mathrm{C}_{3} \mathrm{~S}$ & 3.82 & 4.09 & $\mathrm{HS}+\mathrm{C}_{3} \mathrm{~S}$ & 3.94 & 2.58 \\
\hline $4 \mathrm{M} \mathrm{NaOH}$ & 0.861 & 0.592 & $\mathrm{HS}+\mathrm{C}_{3} \mathrm{~S}$ & 3.05 & 3.52 & $\mathrm{HS}+\mathrm{C}_{3} \mathrm{~S}$ & 2.98 & 1.61 \\
\hline $6 \mathrm{M} \mathrm{NaOH}$ & 0.677 & 0.466 & $\mathrm{HS}+\mathrm{C}_{3} \mathrm{~S}$ & 1.61 & 1.00 & $\mathrm{HS}+\mathrm{C}_{3} \mathrm{~S}$ & 2.43 & 1.38 \\
\hline $8 \mathrm{M} \mathrm{NaOH}$ & 0.558 & 0.384 & $\mathrm{HS}+\mathrm{C}_{3} \mathrm{~S}$ & 2.14 & 1.25 & $\mathrm{HS}+\mathrm{C}_{3} \mathrm{~S}$ & 2.05 & 1.00 \\
\hline $10 \mathrm{MNaOH}$ & 0.475 & 0.327 & $\mathrm{HS}+\mathrm{C}_{3} \mathrm{~S}$ & 1.47 & 0.89 & -- & -- & -- \\
\hline
\end{tabular}

${ }^{*} \mathrm{C}_{3} \mathrm{~S}$ is an abbreviation for the anhydrous calcium silicate phase that comprises $\sim 60$ wt $\%$ of Portland cement $\left(\mathrm{Ca}_{3} \mathrm{SiO}_{5}\right), \mathrm{A}=$ zeolite $\mathrm{A}, \mathrm{HS}=$ hydroxysodalite.

Table 22. Leachability of Table 21 Waste Forms made with Portland Cement Binder.

\begin{tabular}{c|c|c|c|c|c|c|c|c|}
\hline $\begin{array}{c}\text { Total mol } \\
\text { of Na in } \\
\text { PCT } \\
\text { samples }\end{array}$ & $\begin{array}{c}\text { 9each- } \\
\text { ability } \\
(\mathrm{mS} / \mathrm{cm})\end{array}$ & $\begin{array}{c}\mathrm{Na} \text { Leached cured } \\
\left(\mathrm{mol} \cdot 10^{4}\right)\end{array}$ & $\begin{array}{c}\% \mathrm{Na} \\
\text { leached }\end{array}$ & $\begin{array}{c}\mathrm{pH} \text { of } \\
\text { Leachate }\end{array}$ & $\begin{array}{c}\text { Leach- } \\
\text { ability } \\
(\mathrm{mS} / \mathrm{cm})\end{array}$ & $\begin{array}{c}\mathrm{Na} \\
\text { Leached } \\
\left(\mathrm{mol} \cdot 10^{4}\right)\end{array}$ & $\begin{array}{c}\% \mathrm{Na} \\
\text { Leached }\end{array}$ & $\begin{array}{c}\mathrm{pH} \text { of } \\
\text { Leachate }\end{array}$ \\
\hline 0.00305 & 8.40 & 4.20 & 14.0 & 12.3 & 6.6 & 3.30 & 11.0 & 12.2 \\
0.00485 & 15.50 & 7.75 & 16.0 & 12.8 & 11.0 & 5.50 & 11.5 & 12.8 \\
0.00665 & $>100$ & -- & -- & 12.9 & $>100$ & -- & -- & 12.8 \\
0.00845 & $>100$ & -- & -- & 13.2 & $>100$ & -- & -- & 13.1 \\
0.01025 & $>100$ & -- & -- & 13.2 & $>100$ & -- & -- & 13.2 \\
0.01205 & $>100$ & -- & -- & 13.2 & $>100$ & -- & -- & -- \\
\hline
\end{tabular}

-- not determined

The "sodalite" rule of thumb has been touted as a guide to formulating a hydroceramic waste form. ${ }^{22,23,24}$ The minimum in conductivity exhibited by the hydroceramic sample made with $4 \mathrm{M} \mathrm{NaOH}$ mixing solution (Tables 19 and $20,3^{\text {rd }}$ row down) had an overall 1:1:0.8

\footnotetext{
${ }^{22}$ Siemer, D.D., M.W. Grutzeck, B.E. Scheetz, "Comparison of Materials for Making Hydroceramic Waste Forms," 161-167 in "Environmental Issues and Waste Management Technologies in the Ceramic and Nuclear Industries V," edited by G.T. Chandler and X. Feng, Ceram. Trans. Amer. Ceramic Society 107, Westerville, OH. (2000).

${ }^{23}$ Siemer, D.D., J. Olanrewaju, B.E. Scheetz, N. Krishnamurthy and M.W. Grutzeck, "Development of Hydroceramic Waste Forms," 383-390 in "Environmental Issues and Waste Management Technologies in the Ceramic and Nuclear Industries VI,” edited by D.R. Spearing, G.L. Smith and R.L. Putnam, Ceram. Trans. Amer. Ceramic Society 119, Westerville, OH. (2001)

${ }^{24}$ Siemer, D.D., J. Olanrewaju, B.E. Scheetz, and M.W. Grutzeck, "Development of Hydroceramic Waste Forms for INEEL Calcined Waste," 391-398 in "Environmental Issues and Waste Management Technologies in the Ceramic and Nuclear Industries VI," edited by D.R. Spearing, G.L. Smith and R.L. Putnam, Ceram. Trans. Amer. Ceramic Society 119, Westerville, OH. (2001).
} 
Na:Al:Si molar ratio and thus came closest to sodalite's 1:1:1 molar ratio. The minimum in the data seemingly confirms the validity of this rule.

Finally, Portland cement is commonly used to solidify low level wastes of all kinds. Savannah River uses OPC blended with blast furnace slag and fly ash to solidify its Cs- and Srfree nitrate/nitrite bearing SBW to produce a product they call Saltstone. British Nuclear Fuel Limited (BNFL) has used OPC based grouts to solidify Great Britain's "historic" reprocessing waste. Because OPC is widely used for solidification, conceivably OPC might be considered at some future time as a binder for pretreated and calcined/reformed Hanford SBW. Given this possibility, the current study was undertaken in order to determine how a sample of OPC solidified Hanford calcine would perform relative to an equivalent hydroceramic sample. The results show that OPC can be used, but its leachability could be many times higher than a similarly solidified metakaolin/ $\mathrm{NaOH}$ sample.

\section{Conclusions}

Based on performance, hydroceramics made using metakaolin additions to SBW prior to calcination and later as a binder phase are worth considering should the DOE need a contingency waste form to replace vitrification of low activity SBW in storage at DOE's Hanford, Savannah River and INEEL sites. All of the values for \% Na lost by the samples fell below the $11.9 \%$ value for E Glass making all of them at least in principle adequate waste forms. Based on selectivity of zeolite A for Cs and Sr, it seems possible that the hydroceramic waste form can be prepared from SBW without removing $\mathrm{Cs}$ and Sr. If this proves to be true, significant cost savings could be realized vis à vis glass melting.

\section{Publications during the Second Three Years}

Bao, Y. and S. Kwan, D.D. Siemer and M.W. Grutzeck, "Binders for Radioactive Waste Forms made from pretreated Calcined Sodium Bearing Waste," J. Materls. Sci. 39, p. 481-488 (2004).

Siemer, D.D., Performance of Hydroceramic Concretes on Radwaste Leach Tests," 369-397 in "Environmental Issues and Waste Management Technologies in the Ceramic and Nuclear Industries VII," edited by D.R. Spearing, G.L. Smith and S.K. Sundaram, Ceram. Trans. Amer. Ceramic Society 132, Westerville, OH. (2001b).

Siemer, D.D., B.E. Scheetz and M.W. Grutzeck, "Cementitious Solidification of Steam Reformed DOE Salt Waste," DOE's Alaska Meeting 2003. To be published in the Proceedings of the meeting.

Bao, Y. and M.W. Grutzeck, "Solidification of Sodium Bearing Waste using Hydroceramic and Portland Cement Binders," given orally and accepted for publication as part of the Environmental Issues and Waste Management Technologies in the Ceramic and Nuclear Industries Symposium Proceedings at the 2004 Annual Meeting of the American Ceramic Society in Indianapolis IN 2004 (in press).

Bao, Y. and M.W. Grutzeck, "The Effect of Calcination Temperature on the Leachability of Hydroceramic Waste Forms," the paper is written and forms a good part of the above Progress section. It will be submitted shortly.

Grutzeck, Bao, Y., M.W. Grutzeck, Kwan, S., Scheetz, B.E. and D.D. Siemer, "Vapor Hydration Testing of EA Glass and Hydroceramic Waste Forms," In preparation. 
Final Thoughts

Based on the work completed above and the work that is still ongoing under a continuation now under DOE Office of Science, it is proposed to carryout the following additional work during the next three years. Three areas of interest to both Hanford and Savannah River are described below. It is anticipated that the work in progress as well as the proposed work will be completed at the end of three years and thus this will be the last funding requested. It is expected that all joint work will also be completed and joint reports will also be written during this final period of funding.

\section{Optimized $\mathrm{NO}_{\underline{x}}$ Hydroceramic Waste Forms}

Optimized high and low $\mathrm{NO}_{\mathrm{x}}$ hydroceramic waste forms will be produced, characterized, leached (PCT, ANS/ANSI 16.1, MCC-I) and documented. It is proposed to run parallel tests at Savannah River using actual Tank 44 SBW and AN-107. A joint report with SRS will be issued that will serve as a manual for making hydroceramics. The report will also include a discussion of the underlying causes for the observed behavior of the hydroceramic waste forms as a function of time and temperature. Microstructure and phase development will be linked to dissolution data. If it is possible to obtain simulated calcines from actual production runs using a Studsvik reformer or from INEEL these will be incorporated into the program at Penn State

\section{Cold calcination with $\mathrm{Al}+\mathrm{Si}$}

Cold calcination of high $\mathrm{NO}_{\mathrm{x}} \mathrm{SBW}(\mathrm{AN}-107)$ with $\mathrm{Al}+\mathrm{Si}$ will be fully explored. Nitrate/nitrite and ionic content will be tracked as a function of $\mathrm{NaOH}$ concentration. Precipitates will be analyzed for $\mathrm{Cs}$ and $\mathrm{Sr}$. Cr and Tc (Re as simulant) valences will be tracked as well. It is proposed to carry out these experiments in parallel with Savannah River using actual AN-107 waste in storage at Savannah River. It has been found that a combination of equal molar amounts of micrometer sized $\mathrm{Al}$ and $\mathrm{Si}$ powders added to an $8 \mathrm{M} \mathrm{NaOH}$ solution containing molar quantities of $\mathrm{NO}_{3}{ }^{-}$and $\mathrm{NO}_{2}{ }^{-}$will act as reducing agents and convert both nitrate and nitrite to ammonia gas. The beauty of the finding is that the half cell reactions as described below (Table 23) occur slowly over a matter of days providing a controlled reaction that minimizes potentially dangerous off gassing of the ammonia. All off gases can be collected in a bubbler containing $\mathrm{HCl}$. The metals enter the solution phase where they then form insoluble sodium aluminosilicate hydrate precipitates. The residue is normally X-ray amorphous but upon heating in a Parr bomb at $90^{\circ}-180^{\circ} \mathrm{C}$, the precipitate crystallizes to cancrinite. The denitrated/denitrated SBW (hopefully we can go from Type III to Type II or lower), now little more than $\mathrm{NaOH}$ solution can be concentrates/diluted and mixed with metakaolinite and molded and cured at $90^{\circ} \mathrm{C}$ to form a robust and highly stable waste form that contains tectosilicate phases similar to those found in Yucca mountain. An issue under study will be the fate of $\mathrm{Cr}^{6+}$ and Tc (Re simulant) ions in the SBW as well as Cs and Sr. If we are correct, Cs and Sr will also be tied up in the zeolites that form and the $\mathrm{Cr}^{6+}$ and $\mathrm{Tc}$ ions might be reduced to lower valence states and form insoluble precipitates that will be encapsulated or accommodated on lattice sites as a replacement for $\mathrm{Na}$ in the zeolites that form.

The 1:1 molar ratio is important for two reasons: first Si by itself does not work, but in the presence of $\mathrm{Al}$ it does, second a 1:1 ratio causes an insoluble zeolite to precipitate. It settles to the bottom of the reaction flask and should it contain all the Cs in the waste (which it might because Cs tends to be selectively incorporated), the process could be used to separate Cs as well 
as other ions from the remaining, now nitrate and nitrite reduced $\mathrm{NaOH}$. The liquid can then be used to make a hydroceramic by mixing it with metakaolinite and low temperature curing it for a

\section{Table 22. Half Cell reactions for Nitrate and Nitrite Ions reacting with Al and Si Powders in a Concentrated NaOH Solution.}

\begin{tabular}{|c|c|}
\hline 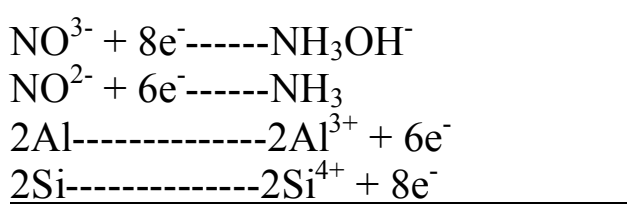 & $\begin{array}{l}-0.12 \mathrm{~V} \\
-0.44 \mathrm{~V} \\
+2.31 \mathrm{~V} \\
+1.69 \mathrm{~V}\end{array}$ \\
\hline $\begin{array}{l}\mathrm{NO}_{3}^{-}+\mathrm{Al}^{0}+--------\mathrm{NH}_{4} \mathrm{OH}^{-}+\mathrm{Al}^{3+} \\
\mathrm{NO}_{3}^{-}+\mathrm{Si}^{0}+-------\mathrm{NH}_{4} \mathrm{OH}^{-}+\mathrm{Si}^{4+} \\
\mathrm{NO}_{2}^{-}+\mathrm{Al}^{0}+--------\mathrm{NH}_{4} \mathrm{OH}^{-}+\mathrm{Al}^{3+} \\
\mathrm{NO}_{2}^{-}+\mathrm{Si}^{0}+--------\mathrm{NH}_{4} \mathrm{OH}^{-}+\mathrm{Si}^{4+}\end{array}$ & $\begin{array}{l}+2.19 \mathrm{~V} \text { (spontaneous) } \\
+1.57 \mathrm{~V} \text { (spontaneous) } \\
+1.86 \mathrm{~V} \text { (spontaneous) } \\
+1.25 \mathrm{~V} \text { (spontaneous) }\end{array}$ \\
\hline
\end{tabular}

few weeks or months. Or, alternately, the cancrinite could be retained and commingled with the developing zeolites in the hydroceramic. It is proposed to study the fate of $\mathrm{TcO}_{4}{ }^{-}\left(\mathrm{Re}^{7+}\right.$ as a stand-in) and $\mathrm{CrO}_{4}{ }^{2-}$ because they too like nitrate and nitrite could be reduced to lower valence state ions that are less mobile and more easily retained by the zeolite matrix.

\section{Dilution of High $\mathrm{NO}_{\underline{x}}$ with $\mathrm{NaOH}$ to make Low $\mathrm{NO}_{\underline{x}} \mathrm{SBW}$}

Dilution is often invoked as a solution for disposing of nuclear waste. In this instance it is more than "tongue in cheek" statement, it might actually provide the best of what hydroceramic waste forms have to offer at a fraction of the cost of the waste form options already discussed above. Let us take the An-107 simulant. It has a $\mathrm{NO}_{\mathrm{x}} / \mathrm{Na}$ molar ratio close to 0.5 . Rather than treating it with thermal or chemical means, one could simply add an equal volume of $15 \mathrm{M} \mathrm{NaOH}$ to it and in this way reduce its relative NOx concentration to less than 0.25 and into the low $\mathrm{NO}_{\mathrm{x}}$ range. Although you now have twice as much waste, $\mathrm{NaOH}$ and metakaolinite are inexpensive and direct solidification will provide a waste form that performs better than EA glass.

Experiments will be completed in order to test this concept.

\section{$\underline{\text { Hydroceramic fill materials }}$}

Hydroceramic fill materials will be formulated using low $\mathrm{NO}_{\mathrm{x}} \mathrm{SBW}$. These are proposed as an alternate to Portland cement used to fill and close empty waste tanks. The leach performance of hydroceramics is expected to be superior to Portland cement both in terms of incorporating sodium and other ions of concern as well as provide secondary protection for stray radionuclides remaining in the tanks. In order to make tank fill materials the hydroceramic grouts must be pourable. Some of the samples reported on above were pourable, so this is not an insurmountable factor. Heat of hydration and strength and leachability could be somewhat compromised by the scale up but work to date suggests this may not be a factor either. Nevertheless these properties will be measured again for hydroceramic grouts made with Types I and II SBW. It is an attractive idea to be able to fill tanks with a monolith zeolite fill material that has all the properties of a loose zeolite in its ability to tie-up stray radionuclides as well as encapsulate and hold existing SBW ions in its lattice sites. Overall leachability would be much lower than Saltstone in as much as the tank fill material is a waste form rather than Portland 
cement. Finally, because the tanks are used to house the hydroceramic grouts, limited or no additional storage facilities would have to be constructed-essentially nothing like Saltstone disposal sites would be needed.

\section{Future Directions}

As we move forward, this final portion of the work will be the most exciting and also the most fruitful. Testing and documentation of optimized hydroceramic monolith production for all types of SBW will be carried out and joint reports will be written. Calcination and steam reforming are expensive to implement and replete with yet unknown pitfalls and as such are not necessarily viable alternates to vitrification in glass plants. Since low $\mathrm{NO}_{\mathrm{x}} \mathrm{SBW}$ can be solidified directly, this is a cost effective alternate. In order to make high $\mathrm{NO}_{\mathrm{x}}$ solidification equally attractive one must consider a different scenario-something like cold calcination which does not require calcination or steam reforming or simple dilution. A SBW can be treated in tank by slowly dispersing enough $\mathrm{Al}$ and $\mathrm{Si}$ powder into the tank to reduce its $\mathrm{NO}_{3}$ and $\mathrm{NO}_{2}$ concentration to some low level $(\sim<25 \mathrm{wt} \%$ of the sodium salt content of the SBW) such that the SBW can then be used to make a hydroceramic waste form without any calcination or steam reforming. In the laboratory, the reduction process is slow and controlled. There is no eruptive gas production. The off gas is ammonia perhaps mixed with some $\mathrm{N}_{2}$. Alternately the waste could be diluted and solidified directly. Work is underway to optimize these processes. A joint report will be issued at the end of the funding period. Finally, it seems as if hydroceramics could be used as tank fill material. They have more than adequate strength and are far superior to Portland cement in encapsulating and isolating radioactive waste ions. Stray radionuclides in the tank should be adsorbed via cation exchange.

Once reaction rates for the process are established, appropriate dissolution testing will be carried out and ${ }^{29} \mathrm{Si}$ and ${ }^{27} \mathrm{Al}$ MAS NMR and TEM will be used to study the atomic-level structure of the solids. X-ray diffraction will be used to examine the degree of crystallinity of the waste forms. Attempts will be made to relate changes in phase chemistry and microstructure to distribution coefficients and dissolution data. VHT will be carried out and reported.

Compressive strength and MOR will be used to determine mechanical behavior. Isothermal calorimetery will be used to test heat flow during setting. Hydroceramics can be cured at $90^{\circ} \mathrm{C}$ open to the air. Excess water will evaporate and radiolysis may not be an issue. Testing of hydroceramics dried at $90^{\circ} \mathrm{C}$ for a month will be tested for susceptibility to radiolysis in Penn State's ${ }^{60}$ Co source.

Knowing that simulated waste is not an adequate predictor, a major portion of the proposed work on actual Tank 44 and An-107 low activity SBW will be carried out by Dr. Carol Jantzen at Savannah River who currently is running parallel testing using Tank 44 waste. She will take our best simulation recipes and best calcination schemes and recreate the same waste forms that we are using at Penn State. In the next funding period she will be making hydroceramic samples from Tank 44 waste by direct solidification, and she will be studying the cold calcination of AN-107 SBW followed by direct solidification. She will leach the samples and begin to explore how best to control these species in actual SBW and whether-or-not cold calcination is a viable technique. The value of running parallel studies of this type is self-evident. Given these data, it is expected that it will be possible to piece together a coherent picture of how the crystal and phase evolution of an actual di-phasic zeolite-containing waste form made from low activity SBW governs its performance and its durability once placed into service. Joint reports as well as individual investigator reports will be generated by the end of the project. 


\section{Final Justifications}

At this point in time it has been demonstrated that hydroceramic waste forms and/or a hydroceramic binder could be less costly and also a safer alternatives to vitrification of SBW present in tanks at Savannah River and Hanford. DOE has been presented with a rare opportunity to optimize a new technology that may well outperform current options at a lower cost both in terms of monetary investment and safety because processing can potentially be carried out at $90^{\circ} \mathrm{C}$. By endorsing the technology, DOE has the chance to pretreat existing waste streams to make them more amenable to the zeolitization process. Unlike INEEL we have the opportunity to add calcination aids to the waste stream prior to calcination. We have choices of oxidizing/reducing environments and the addition of calcination aids such as clays and reducing agents prior to calcination. Furthermore, we have the choice of separation or no separation of Cs and Sr. Hydroceramics can be used to solidify SBW defined as HLW. It seems to us that it would be less expensive and certainly safer to workers if performance based definitions were adopted and state and federal regulations were changed to accommodate the new regulations. Hydroceramics will ultimately be good enough to allow one to use them as tank fill which is on site burial but used a much less leachable product than Saltstone.

Hydroceramics could play an important role in our nation's waste management scheme. The estimated 100 million gallons of SBW defined as HLW could be solidified as hydroceramic at lower cost using a mixing and curing process that is inherently safer than vitrification. Processing would be carried out at $90^{\circ} \mathrm{C}$ rather than $1100^{\circ} \mathrm{C}$. By casting the hydroceramic in the same stainless steel canister as SRL's glass, without melting, costs could be reduced significantly. Rather than $\$ 1,000,000$ per canister, it is conceivable that it could cost little more than the cost of the canister and the labor to fill it, but this is yet to be seen as the project evolves. These are rough estimates, but we are convinced that hydroceramic waste forms could turn the SBW issue around. Many of the current problems concerning separation of $\mathrm{Cs}$ and $\mathrm{Sr}$, volatile content, Tc and TRU, and volume increases due to vitrification might simply go away if hydroceramics are proven to work as well as we think they can. 